\title{
Regulation of Skeletal Muscle Glucose Transport and Glucose Metabolism by Exercise Training
}

\author{
Parker L. Evans ${ }^{1,2,3}$, Shawna L. McMillin $1,2,3 \oplus$, Luke A. Weyrauch ${ }^{1,2,3}$ and \\ Carol A. Witczak 1,2,3,4,* \\ 1 Department of Kinesiology, East Carolina University, Greenville, NC 27858, USA; \\ evanspa17@students.ecu.edu (P.L.E.); mcmillins15@students.ecu.edu (S.L.M.); \\ weyrauchl16@students.ecu.edu (L.A.W.) \\ 2 Department of Physiology, Brody School of Medicine, East Carolina University, Greenville, NC 27834, USA \\ 3 East Carolina Diabetes \& Obesity Institute, East Carolina University, Greenville, NC 27834, USA \\ 4 Department of Biochemistry \& Molecular Biology, Brody School of Medicine, East Carolina University, \\ Greenville, NC 27834, USA \\ * Correspondence: witczakc@ecu.edu; Tel.: +1-252-744-1224
}

Received: 8 September 2019; Accepted: 8 October 2019; Published: 12 October 2019

\begin{abstract}
Aerobic exercise training and resistance exercise training are both well-known for their ability to improve human health; especially in individuals with type 2 diabetes. However, there are critical differences between these two main forms of exercise training and the adaptations that they induce in the body that may account for their beneficial effects. This article reviews the literature and highlights key gaps in our current understanding of the effects of aerobic and resistance exercise training on the regulation of systemic glucose homeostasis, skeletal muscle glucose transport and skeletal muscle glucose metabolism.
\end{abstract}

Keywords: aerobic exercise; blood glucose; functional overload; GLUT; hexokinase; insulin resistance; resistance exercise; SGLT; type 2 diabetes; weightlifting

\section{Introduction}

Exercise training is defined as planned bouts of physical activity which repeatedly occur over a duration of time lasting from weeks to years. For the purposes of this review article, we have divided exercise training into two general categories: (1) Aerobic exercise training, which consists of weight bearing and non-weight bearing activities; and (2) resistance exercise training, which consists of weight bearing activities that act against an external load. Both types of training can be developed as progressive programs, which is defined as a planned increase in the duration, frequency, and/or intensity of the activity throughout the training period. The objective of this article was to review the literature on the effects of aerobic and resistance exercise training on the regulation of systemic glucose homeostasis, skeletal muscle glucose transport and glucose metabolism, and then to highlight gaps in our current understanding of these key adaptations. To accomplish this objective, we performed searches of the scientific literature utilizing Google Scholar, Highwire, PubMed, and Scopus to identify studies that contained the following keywords (alone and in combination): Aerobic exercise; aerobic training; blood glucose; cycling; glucose homeostasis; elastic band; exercise; exercise adaptations; exercise training; functional overload; glucose homeostasis; glucose metabolism; glucose transporter; glucose uptake; facilitative glucose transporter (GLUT); glycolysis; glycolytic flux; glycogen content; glycogen synthesis; hexosamine pathway; ladder climbing; overload; pentose phosphate pathway; resistance exercise; resistance training; resistance training adaptations; running; sodium-dependent glucose co-transporter (SGLT); skeletal muscle; sodium-dependent glucose co-transporter; swimming; 
synergist ablation; treadmill; type 2 diabetes; weight lifting; weight training; wheel cage. The identified articles were then divided into either the aerobic or resistance exercise training categories based on whether an external load was acted against during the exercise. Only studies using a 6-week training intervention or longer were selected for this review, with the exception of one article. The training period for this article was 3 weeks, and that information is clearly indicated in that section. We allowed this one exception because it highlighted a key gap in the current literature regarding the mechanism(s) underlying the effects of aerobic or resistance exercise training on muscle glucose transport.

\section{Models of Aerobic and Resistance Exercise Training}

Aerobic exercise training exists in a wide variety of forms, and the following list includes examples of aerobic exercises that are routinely performed by individuals in self-initiated aerobic training programs: aerobic classes, cycling, dancing, jumping jacks, jumping rope, rowing, running, skating, skiing, swimming and walking. In aerobic training research studies, the most common forms of exercise utilized in human subjects are treadmill running and cycle ergometer training [1-4], whereas in animal studies the most common form is treadmill running [5-7]. Resistance exercise training also exists in a variety of forms, and the following list includes examples of exercises that are routinely performed with weights or elastic bands by individuals in self-initiated resistance training programs: bicep curl, shoulder press, bench press, barbell squat, bent over row, and lateral band walk. In resistance training research studies, the most common form of exercise utilized with human subjects is a weight-bearing program involving the upper body, lower body and abdomen [8-10]. In contrast, in resistance training studies involving rodents the most common form of exercise is weighted ladder climbing [11-14]. While aerobic exercise training activities are naturally common in both humans and animals due to survival instincts (i.e., chasing down prey or running away from a predator), resistance exercise training activities (i.e., carrying an external load) are not. Thus, there are fewer studies that have investigated the physiological effects of resistance exercise training in animal models. To overcome this challenge, a surgical approach was developed that rapidly and reproducibly induces loading/functional overload in rodent skeletal muscle via the removal of one or more synergist muscles [15]. Importantly, numerous studies have shown that functional overload induces the same adaptations as resistance exercise training in skeletal muscle, including increases in muscle size and muscle strength [16-23].

\section{Aerobic and Resistance Exercise Training-Induced Adaptations}

Aerobic exercise training and resistance exercise training are both well-known for their ability to induce specific beneficial adaptations in the human body. For aerobic exercise training, the predominant adaptations are in the cardiorespiratory system and include: (1) A decrease in resting heart rate [24-26]; (2) a decrease in resting blood pressure [24-26]; and (3) an increase in maximal oxygen uptake $\left(\mathrm{VO}_{2}\right.$ $\max )[27,28]$. For resistance exercise training, the predominant adaptations are in the musculoskeletal system and include: (1) An increase in muscle mass [29-31]; (2) an increase in muscle strength [32]; and (3) an increase in bone density [33,34]. For a thorough review on the effects of aerobic and resistance training on these cardiovascular and musculoskeletal adaptations see the following article: [35]. In addition to these adaptations, both aerobic exercise training and resistance exercise training are well-known for their ability to restore systemic glucose homeostasis in individuals with the metabolic disease type 2 diabetes. In the following section on the regulation of systemic glucose homeostasis, we describe how blood glucose levels are regulated in a healthy state, and then review the current literature regarding how they are impacted by type 2 diabetes and exercise training.

\section{Regulation of Systemic Glucose Homeostasis}

\subsection{Regulation in Healthy Individuals}

In healthy individuals, systemic glucose homeostasis is tightly regulated to maintain fasted blood glucose levels at $<100 \mathrm{mg} / \mathrm{dl}(<5.5 \mathrm{mM})$, glycated hemoglobin A1c (HbA1c) levels at $<5.7 \%$, and blood 
glucose levels at $<140 \mathrm{mg} / \mathrm{dl}(<7.8 \mathrm{mM}) 2 \mathrm{hrs}$. following an oral glucose challenge [36]. There are multiple tissues that coordinately regulate blood glucose levels, and the role of these tissues varies dependent on the fed or fasted state of the individual. In the fasted state, the liver maintains systemic glucose homeostasis via glycogenolysis and gluconeogenesis. In the fed state, glucose released from the digestive system into the bloodstream causes a rise in blood glucose levels that triggers an increase in insulin production and release from the $\beta$-cells of the pancreas. The rise in blood insulin levels triggers the following events: (1) inhibition of liver glycogenolysis, gluconeogenesis and glucose secretion; (2) stimulation of adipose tissue glucose uptake; and (3) stimulation of skeletal muscle glucose uptake. Thorough reviews on the regulation of systemic glucose homeostasis are provided in the following articles: [37-39].

\subsection{Dysregulation in Type 2 Diabetes}

Type 2 diabetes is a chronic metabolic disease characterized by a dysregulation of systemic glucose homeostasis. It is diagnosed when fasted blood glucose levels are $>126 \mathrm{mg} / \mathrm{dL}(>7.0 \mathrm{mM}), \mathrm{HbA} 1 \mathrm{c}$ levels are $>6.5 \%$, and blood glucose levels are $>200 \mathrm{mg} / \mathrm{dL}(>11.1 \mathrm{mM}) 2 \mathrm{hrs}$. following an oral glucose challenge [36]. While the exact causes of type 2 diabetes remain incompletely understood, numerous studies have linked impairments in key glucoregulatory functions in the pathogenesis of the disease. These include: (1) Impaired insulin-mediated inhibition of hepatic glucose output [40]; (2) impaired insulin-stimulated glucose uptake into adipose tissue [41,42]; (3) impaired release of insulin from the pancreas; and (4) impaired insulin-stimulated glucose uptake into skeletal muscle [43,44]. Thorough reviews on the tissues and physiological processes involved in the dysregulation of systemic glucose homeostasis in type 2 diabetes are provided in the following articles: [45-47].

\subsection{Effects of Aerobic Training in Type 2 Diabetes}

Aerobic exercise training is well-known for its ability to improve systemic glucose control in both individuals and animals with type 2 diabetes. Studies in both men and women with type 2 diabetes have demonstrated the following beneficial effects: (1) 8 weeks of aerobic walking ( $30 \mathrm{~min} /$ day, 3 days/week) decreased $\mathrm{HbA1c}$ levels $18 \%$ [8]; (2) 12 weeks of bicycle training (60 min/day, 3 days/week) decreased fasted blood glucose levels 14\% [2]; (3) 16 weeks of cardiovascular machine-based training ( $60 \mathrm{~min} /$ day, 3 days/week at 60-65\% max heart rate) decreased fasted blood glucose levels $\sim 10 \%$ and $\mathrm{HbA1c}$ levels $\sim 1 \%$ [48]; (4) 16 weeks of interval walking ( 3 min fast-3 min slow cycles; $60 \mathrm{~min} / \mathrm{session}, 5$ sessions/week) decreased fed plus fasted blood glucose levels 8.5\% [3]; (5) 24 weeks of aerobic walking, running, cycling or calisthenic exercises (60 min/day, 4 days/week at $60-70 \%$ max heart rate) decreased fasted blood glucose levels $\sim 28 \%$ and HbA1c levels 7\% [49]; (6) 26 weeks of progressive treadmill running or cycle ergometer training (15-20 min/day, 3 days/week at $60 \%$ max heart rate, up to $45 \mathrm{~min} /$ day, 3 days/week at 75\% max heart rate) decreased HbA1c levels 7\% [4]; (7) 36 weeks of treadmill walking decreased $\mathrm{HbA1c}$ levels $~ 0.5 \%$ in subjects with the most severe diabetes (HbA1c $>7.0 \%$ ) [1]; (8) 52 weeks of progressive treadmill running or cycle ergometer training (20 min/day, 2-3 days/week at $60 \%$ max heart rate up to $60 \mathrm{~min} /$ day, 2-3 days/week at 75\% max heart rate) decreased HbA1c levels 15\% [50]; and (9) 8 years of aerobic machine training (90 min/day, 3 days/week at $50-80 \% \mathrm{VO}_{2}$ max) decreased $\mathrm{HbA1c}$ levels $\sim 22 \%$ [51]. Similarly, studies in rodents demonstrated the following beneficial effects: (1) 7 weeks of motorized wheel exercise (1 hour/day, 5 days/week at 5.2 meters $/ \mathrm{min}$ ) decreased blood glucose levels $\sim 12 \%$ in db/db mice compared to sedentary controls [6]; (2) 8 weeks of progressive treadmill running ( $8 \%$ grade, $18 \mathrm{~m} / \mathrm{min}, 5$ days/week, $40 \mathrm{~min} /$ day up to $120 /$ day) decreased blood glucose levels $\sim 20 \%$ at 15 and $30 \mathrm{~min}$ following an oral glucose challenge in Zucker fatty rats compared to sedentary controls [5]; (3) 12 weeks of voluntary wheel running decreased fasting blood glucose levels $\sim 20 \%$ in diabetic $\mathrm{db} / \mathrm{db}$ mice compared to sedentary controls [52]; (4) 12 weeks of swimming ( 1 hour/day, 3 days/week) decreased blood glucose levels $\sim 11 \%$ and HbA1c levels $\sim 7 \%$ in diabetic Zucker fatty rats compared to sedentary controls [53,54]; (5) 12 weeks of treadmill running (up to $17 \%$ incline, 10-15 meters/minute, 1 hour/day, 5 days/week) decreased fasting blood glucose $~ 14 \%$ in fatty 
Zucker rats compared to sedentary controls [7]; and (6) 13 weeks of swimming resulted in $60 \%$ lower fasted glucose, $52 \%$ lower fed glucose, as well as fatty Zucker rats were significantly more glucose tolerant than sedentary controls [55].

\subsection{Effects of Resistance Training in Type 2 Diabetes}

Resistance exercise training has been shown to improve systemic glucose control in both individuals and rodents with type 2 diabetes. Studies in both men and women with type 2 diabetes have demonstrated the following beneficial effects: (1) 8 weeks of progressive free weight and weight machine training involving arms and legs ( 2 days/week, 7 exercises/session, 3 sets of 10 repetitions at $60 \%$ 1 repetition max up to $100 \%$ of initial 1 repetition max) decreased HbA1c levels $~ 18 \%$ [8]; (2) 16 weeks of weight machine training involving arms and legs ( 3 days/week, 5 exercises/session, 8 repetitions at $60-80 \%$ max, up to 8 repetitions at 70-80\% max) reduced $\mathrm{HbA} 1 \mathrm{c}$ levels 13\% [9]; (3) 16 weeks of progressive free weight and weight machine training of arms and legs (3 days/week, 10 exercises/session, progressing from 3 to 6 sets/week of 10-15 max repetitions) decreased fasted blood glucose levels $\sim 28 \%$ and $\mathrm{HbA} 1 \mathrm{c}$ levels $~ 14 \%$ [56]; (4) 16 weeks of free weight and weight machine training of arms and legs (3 days/week, 7 exercises/session, 10 max repetitions) decreased fasted blood glucose levels $\sim 7 \%$ and $\mathrm{HbA} 1 \mathrm{c}$ levels $~ 5 \%$ [48]; (5) 24 weeks of progressive free weight and weight machine training of the arms, legs and abdomen (3 days/week, 9 exercises/session, 8-10 repetitions at 50-60\% max progressing to 10 repetitions at 75-85\% max) lowered HbA1c levels 2\% [10]; (6) 24 weeks of weight machine training of arms and legs (4 days/week, 8 exercises/session, 2-3 sets of 8-10 max repetitions) decreased fasted blood glucose levels $\sim 9 \%$ and HbA1c levels 3\% [49]; (7) 24 weeks of weight machine (i.e., bioDensity ${ }^{\mathrm{TM}}$ ) training of arms and legs (1 day/week, 5-10 $\mathrm{min} /$ day) reduced fasted blood glucose levels $\sim 11 \%$ and $\mathrm{HbA} 1 \mathrm{c}$ levels $\sim 8 \%$ in subjects with the most severe diabetes (HbA1c $>7.5 \%$ ) [57]; (8) 26 weeks of progressive machine weight training of arms, legs and abdomen (2 days progressing to 3 days/week, 7 exercises/session, 8-12 max repetitions) reduced HbA1c levels $\sim 4 \%$ [4]; and (9) 52 weeks of progressive machine weight training of arms, legs and abdomen (10 exercises/session, 1 set of 1 max repetitions, 2 days/week up to 3 sets of 8-10 max repetitions, 3 days/week) decreased fasted blood glucose levels $\sim 15 \%$ and $\mathrm{HbA1c}$ levels $\sim 8 \%$ [50].

In addition, studies in rodents have demonstrated similar beneficial effects of resistance training on systemic glucose control. These studies found the following effects: (1) 7 weeks of progressive weighted ladder climbing $\left(80^{\circ}\right.$ incline, 10 climbs/session, 5 sessions/week starting with an external load equal to $10 \%$ body weight and increasing up to $70 \%$ body weight) decreased fasted blood glucose levels $\sim 30 \%$ in monosodium glutamate diet-induced diabetic rats [13]; (2) 8 weeks of progressive weighted ladder climbing $\left(85^{\circ}\right.$ incline, 10 climbs/session, 3 sessions/week starting with an external load equal to $50 \%$ body weight and increasing up to $80 \%$ max load) reduced fasted blood glucose levels $\sim 55 \%$ and improved glucose tolerance $50 \%$ in diabetic Zucker fatty rats compared to sedentary controls [11]; and (3) 10 weeks of isometric wire hang training ( $3 \mathrm{~min} /$ bout, 3 bouts/session, 5 sessions/week) decreased blood glucose levels $\sim 30 \% 2$ hrs. following an intraperitoneal glucose challenge in high fat diet-induced hyperglycemic C57BL/6N mice compared to sedentary controls [58].

\section{Skeletal Muscle Glucose Transport}

Skeletal muscle plays a critical role in maintaining blood glucose homeostasis. Studies in healthy individuals have demonstrated that in the post-prandial state that skeletal muscle is responsible for taking up $70-90 \%$ of the glucose from the blood $[59,60]$. The following sections review the current literature and highlight key gaps in our current understanding of the processes involved in the regulation of glucose transport in skeletal muscle as well as the ability of both aerobic and resistance exercise training to alter this process.

Skeletal muscle takes up glucose from the extracellular fluid into the cell via a surface membrane sugar transport protein [61]. There are two major families of sugar transport proteins found in mammalian cells: (1) The solute carrier family 2 (gene family SLC2) which consists of fourteen 
facilitative glucose transporters (GLUTs 1-14); and (2) the solute carrier family 5 (gene family SLC5) which consists of six sodium-dependent glucose co-transporters (SGLTs 1-6). These two families differ in their structural and functional characteristics. The GLUTs possess 12 transmembrane domains, an N-linked glycosylation motif [62,63], and transport sugars via facilitated diffusion; whereas, the SGLTs possess 14-15 transmembrane domains [64] and couple glucose with sodium transport to facilitate cellular glucose uptake [65]. In addition to these characteristics, the GLUTs and SGLTs can also vary greatly in their ability to transport different sugars, their subcellular localization, as well as their susceptibility to chemical inhibitors. For a thorough description of these characteristics, please see the following reviews on this topic [62,66-68]. Skeletal muscle expresses many sugar transporter isoforms, including: GLUT1, GLUT3, GLUT4, GLUT5, GLUT6, GLUT8, GLUT10, GLUT11, GLUT12, SGLT1, SGLT2, SGLT3, and SGLT4; and Table 1 provides a list of the different skeletal muscle models in which each of these sugar transporter isoforms has been observed.

Table 1. Skeletal muscle sugar transporters. Members of the facilitated glucose transporters (GLUT) and sodium-dependent glucose cotransporter (SGLT) families observed in human and rodent skeletal muscle.

\begin{tabular}{|c|c|c|c|}
\hline Transporter & Gene & Muscle Models & References \\
\hline \multirow{5}{*}{ GLUT1 } & \multirow{5}{*}{ SLC2A1 } & Human muscle & {$[69,70]$} \\
\hline & & $\mathrm{C} 2 \mathrm{C} 12$ & {$[71,72]$} \\
\hline & & Mouse muscle & {$[73,74]$} \\
\hline & & L6 myotubes & {$[72,75]$} \\
\hline & & Rat muscle & {$[76,77]$} \\
\hline \multirow{5}{*}{ GLUT3 } & \multirow{5}{*}{ SLC2A3 } & Human muscle & {$[78,79]$} \\
\hline & & $\mathrm{C} 2 \mathrm{C} 12$ & {$[71]$} \\
\hline & & Mouse muscle & {$[73,80]$} \\
\hline & & L6 myotubes & {$[81,82]$} \\
\hline & & Rat muscle & {$[83,84]$} \\
\hline \multirow{5}{*}{ GLUT4 } & \multirow{5}{*}{ SLC2A4 } & Human muscle & {$[85,86]$} \\
\hline & & C2C12 & {$[71,72]$} \\
\hline & & Mouse muscle & {$[87,88]$} \\
\hline & & L6 myotubes & {$[82]$} \\
\hline & & Rat muscle & {$[76,89]$} \\
\hline \multirow{5}{*}{ GLUT5 } & \multirow{5}{*}{ SLC2A5 } & Human muscle & {$[90,91]$} \\
\hline & & $\mathrm{C} 2 \mathrm{C} 12$ & [71] \\
\hline & & Mouse muscle & [92] \\
\hline & & L6 myotubes & [93] \\
\hline & & Rat muscle & [94] \\
\hline \multirow{2}{*}{ GLUT6 } & \multirow{2}{*}{ SLC2A6 } & $\mathrm{C} 2 \mathrm{C} 12$ & [71] \\
\hline & & Mouse muscle & {$[73,95]$} \\
\hline \multirow{2}{*}{ GLUT8 } & \multirow{2}{*}{ SLC2A8 } & Human muscle & [96] \\
\hline & & Mouse muscle & [95] \\
\hline \multirow{2}{*}{ GLUT10 } & \multirow{2}{*}{ SLC2A10 } & Human muscle & [97] \\
\hline & & Mouse muscle & {$[73,95]$} \\
\hline GLUT11 & SLC2A11 & $\begin{array}{l}\text { Human vastus lateralis } \\
\text { (slow-twitch fibers) }\end{array}$ & [98] \\
\hline \multirow{4}{*}{ GLUT12 } & \multirow{4}{*}{ SLC2A12 } & Human muscle & {$[99,100]$} \\
\hline & & $\mathrm{C} 2 \mathrm{C} 12$ & {$[71,101]$} \\
\hline & & Mouse muscle & [102] \\
\hline & & Rat muscle & [103] \\
\hline \multirow{2}{*}{ SGLT1 } & \multirow{2}{*}{ SLC5A1 } & Human muscle & [104] \\
\hline & & Mouse muscle & [105] \\
\hline SGLT2 & SLC5A2 & Mouse muscle & [105] \\
\hline \multirow{2}{*}{ SGLT3 } & \multirow{2}{*}{ SLC5A4 } & Human muscle & [106] \\
\hline & & Mouse muscle & [107] \\
\hline SGLT4 & SLC5A9 & Human muscle & [104] \\
\hline
\end{tabular}




\subsection{Regulation of Basal Glucose Transport}

GLUT1 is largely considered the GLUT isoform responsible for basal/non-insulin stimulated muscle glucose transport due to its localization predominantly on the muscle cell surface $[76,77,108]$. This postulation is consistent with muscle-specific GLUT1 overexpression mouse studies demonstrating a positive relationship between increasing GLUT1 levels and increases in basal muscle glucose transport [108,109]. However, additional scrutiny of these studies demonstrated that despite an $\sim 40$-fold increase in GLUT1 protein in the muscles from the overexpression mice, there was only an $\sim 9$-fold increase in basal muscle glucose transport [109]. This finding suggests that in skeletal muscle the mechanism regulating glucose transport via GLUT1 is more complex than just cell surface expression. Consistent with that interpretation, recent work in L6 myoblasts demonstrated that mutation of GLUT1 Ser490 to Ala490 decreased basal muscle glucose transport $44 \%$ with only a $17 \%$ reduction in cell surface localization [75]. Additional studies are needed utilizing muscle-specific GLUT1 null models to definitively assess the contribution of GLUT1 to basal skeletal muscle glucose uptake.

\subsection{Regulation of Acute Insulin-And Exercise/Contraction-Stimulated Glucose Transport}

GLUT4 is the most abundant glucose transporter isoform expressed in skeletal muscle [110]. Unlike GLUT1 which resides almost exclusively on the cell surface, in the basal (non-insulin stimulated) state, GLUT4 resides both on the cell surface ( $\sim 20 \%$ of total GLUT4 protein) and in GLUT4 storage vesicles within the cell ( $\sim 80 \%$ of total GLUT4 protein) [111,112]. In response to stimulation by insulin or exercise/muscle contraction, GLUT4 translocates from intracellular storage vesicles to the muscle cell surface where it plays an essential role in mediating acute insulin- and exercise/muscle contraction-stimulated muscle glucose transport [87]. Notably, skeletal muscle insulinand contraction-stimulated GLUT4 translocation to the plasma membrane and t-tubules is additive suggesting potential distinct pools of GLUT4 $[89,113,114]$. The intracellular signaling and docking mechanisms by which GLUT4 translocation occurs has been and continues to be extensively studied. Thorough reviews on this topic can be found in the following papers: [111,115-118].

\subsection{Dysregulation of Insulin-Stimulated Glucose Transport in Type 2 Diabetes}

In individuals with type 2 diabetes, the ability of insulin to stimulate skeletal muscle glucose transport is impaired [119-122]. Studies in both human and rodents have demonstrated that this impairment in insulin-stimulated muscle glucose transport is due to a disruption in GLUT4 translocation to the muscle cell surface rather than an alteration in total muscle GLUT4 protein content $[115,123]$. While insulin-stimulated muscle GLUT4 translocation and glucose transport is impaired in type 2 diabetes, the ability of acute bouts of exercise or muscle contractile activity to stimulate GLUT4 translocation and glucose transport remains intact [124-127].

\subsection{Regulation of Aerobic Exercise Training-Induced Glucose Transport}

Aerobic exercise training has been shown to increase GLUT4 protein levels $20-70 \%$ in human [128-136] and rodent skeletal muscle [137-141], suggesting that aerobic training would enhance acute insulin- and exercise/muscle contraction-stimulated muscle glucose transport. Consistent with this prediction, studies have demonstrated that aerobic training enhances insulin-stimulated muscle glucose disposal 20-100\% [131,134,142-146]. However, consistent with the aerobic training effect of increased reliance on lipid utilization, work in human vastus lateralis muscle has demonstrated that only 3 weeks of aerobic training decreases exercise-stimulated muscle GLUT4 translocation and glucose transport at a given workload [128]. Additional studies are needed examining the relationship between alterations in muscle glucose transport during exercise and changes in total muscle GLUT4 protein levels following a long-term ( $>6$ weeks) aerobic training program.

Alterations in the intracellular signaling mechanisms regulating GLUT4 translocation represent one possible explanation for how aerobic exercise training alters muscle glucose transport. An additional 
explanation is the involvement of other glucose transporter isoforms (Figure 1). Only a few studies have examined the effects of aerobic exercise training on GLUT isoforms other than GLUT4, and these studies examined GLUT1, GLUT5, GLUT8 and GLUT12. One study in humans did not see any alteration in muscle GLUT1 protein content following 6 weeks of a progressive cycling program (30 min at $70-75 \%$ max heart rate up to $50 \mathrm{~min}$ at $70-85 \%$ max heart rate) and strikingly saw a $72 \%$ decrease in GLUT5 protein levels [127]. In the muscle of endurance trained collegiate athletes, GLUT8 and GLUT12 mRNA levels did not differ from sedentary controls [147], but GLUT12 protein levels increased $104 \%$ in human vastus lateralis following 6 weeks of a progressive cycling program [129]. However, none of these studies completely include or exclude the potential involvement of GLUT1, GLUT8 or GLUT12 in this process. Since aerobic exercise training does not stimulate basal muscle glucose transport, any additional transporters involved in aerobic training-induced changes in muscle glucose transport would have to possess the ability to either alter their transport activity via post-translational modification and/or translocate to the muscle cell surface. Intriguingly, studies have demonstrated that GLUT1, GLUT8 and GLUT12 each possess at least one of these characteristics. As described above, while GLUT1 is localized predominantly on the muscle cell surface $[76,77,108]$, its transport activity can also be regulated by phosphorylation on Ser490 [75] and Ser226 [148]. In contrast, both GLUT8 and GLUT12 contain an endocytic dileucine motif, and studies in 3T3L1 adipocytes or HEK293 cells have shown that mutation of this motif alters their cell surface localization $[149,150]$. Additional studies are needed to not only investigate the role of GLUT1, GLUT8 or GLUT12 in this process but also to assess whether other GLUT isoforms may be involved.

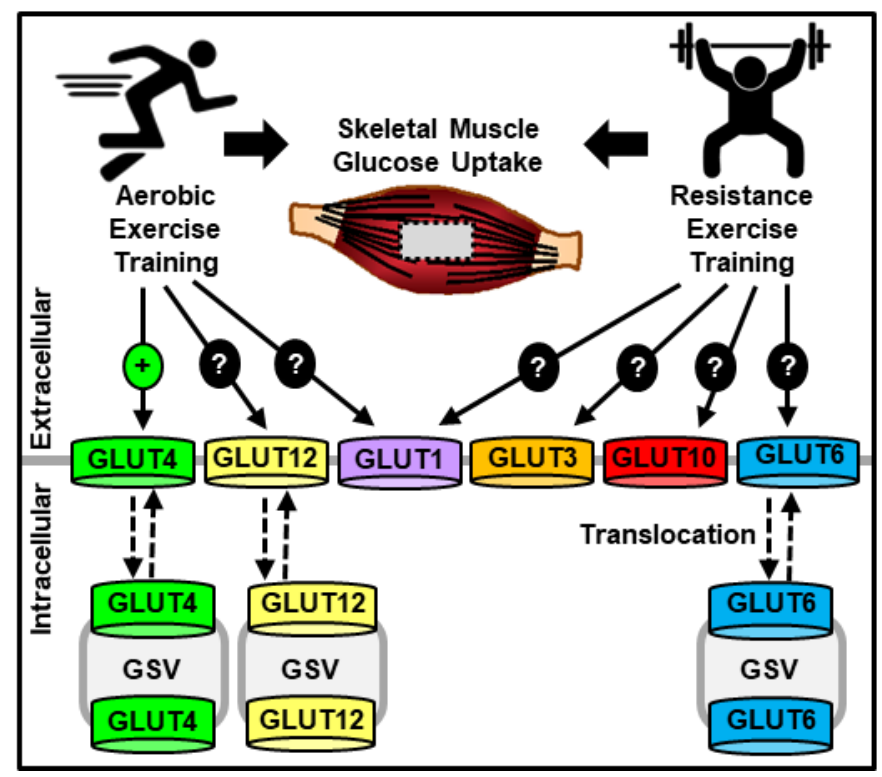

Figure 1. Model of aerobic and resistance exercise training effects on skeletal muscle glucose transporters (GLUTs). Legend: GSV = GLUT storage vesicle.

\subsection{Regulation of Resistance Exercise Training-Induced Glucose Transport}

Resistance exercise training increases glucose transport into skeletal muscle [151-153], and in rodent models it is clear that this increase in glucose uptake occurs independent of changes in muscle mass $[152,153]$. However, unlike aerobic exercise training that consistently increases muscle GLUT4 protein content, the ability of resistance exercise training to increase GLUT4 levels is less clear (Figure 1). While 6 weeks of intense progressive resistance training increased GLUT4 protein levels $\sim 40 \%$ in the vastus lateralis of men with type 2 diabetes [151], the same training regimen failed to significantly alter muscle GLUT4 protein content in the healthy controls [151]. In addition, in mouse rectus femoris muscle, 10 weeks of isometric resistance exercise training increased GLUT4 protein levels 70\% [58]; yet, no change in GLUT4 protein levels was observed in rat gastrocnemius following 7 weeks of progressive 
weighted vertical ladder climbing [13]. The findings suggesting no role for GLUT4 in resistance training-induced muscle glucose transport are supported by recent work in muscle-specific GLUT4 knockout mice that demonstrated no impairment in plantaris muscle glucose transport following 5 days of functional overload, a model of resistance exercise training [73]. Collectively these results suggest that GLUT4 is not the sole mediator of resistance exercise training-induced increases in muscle glucose transport and propose that additional glucose transporter(s) play a role in this process.

While the identity of these additional glucose transporter(s) is currently unknown, studies have suggested a possible role for GLUT1, GLUT3, GLUT6, GLUT10 and/or SGLT3. In the vastus lateralis muscle of individuals with type 2 diabetes, 16 weeks of progressive resistance training increased SGLT3 mRNA and protein levels compared to sedentary controls [106]. However, work in Xenopus oocytes did not demonstrate any D-glucose transport by SGLT3 [107], and recent work in mouse plantaris muscle demonstrated no effect of the chemical SGLT inhibitor, phlorizin, on functional overload-induced muscle glucose transport [73]. Together these findings suggest that SGLTs are not necessary for loading-mediated muscle glucose transport. In the plantaris muscle of both wild-type and muscle-specific GLUT4 knockout mice, 5 days of functional overload increased the protein levels of GLUT1 150-300\%, GLUT3 130\%, GLUT6 250\% and GLUT10 200-250\% [73], suggesting a role for one or more of these GLUT isoforms in resistance training-induced muscle glucose transport. This finding is consistent with studies performed in cardiac, smooth or skeletal muscle that investigated these GLUT isoforms in the regulation of muscle cell growth, development, and redox buffering. These studies demonstrated: (1) An $~ 150 \%$ increase in GLUT1 protein levels following pressure overload in the heart [154]; (2) a transient but $~ 900 \%$ increase in GLUT3 mRNA levels during L6 myocyte fusion [83]; (3) an $~ 45 \%$ increase in GLUT3 protein levels in L6 myotubes following long-term insulin-like growth factor-1 exposure [81]; and (4) an increase in oxidative stress following loss of function mutations in GLUT10 arterial smooth muscle cells $[155,156]$. Future studies in muscle-specific GLUT knockout mouse models are needed to fully assess the role of any of these GLUT isoforms in the regulation of resistance training-induced muscle glucose transport.

\section{Skeletal Muscle Glucose Metabolism}

Glucose transported into skeletal muscle is phosphorylated by hexokinase to form glucose-6-phosphate thereby trapping it in the cell. After this step there are four main cellular fates of glucose, and the partitioning of glucose into these metabolic pathways has critical consequences for future increases in muscle glucose transport and phosphorylation. The following sections review the current literature and highlight key gaps in our current understanding of the important enzymes and metabolites involved in the regulation of skeletal muscle glucose metabolism, as well as the ability of both aerobic and resistance exercise training to alter these metabolic pathways (Figure 2). 


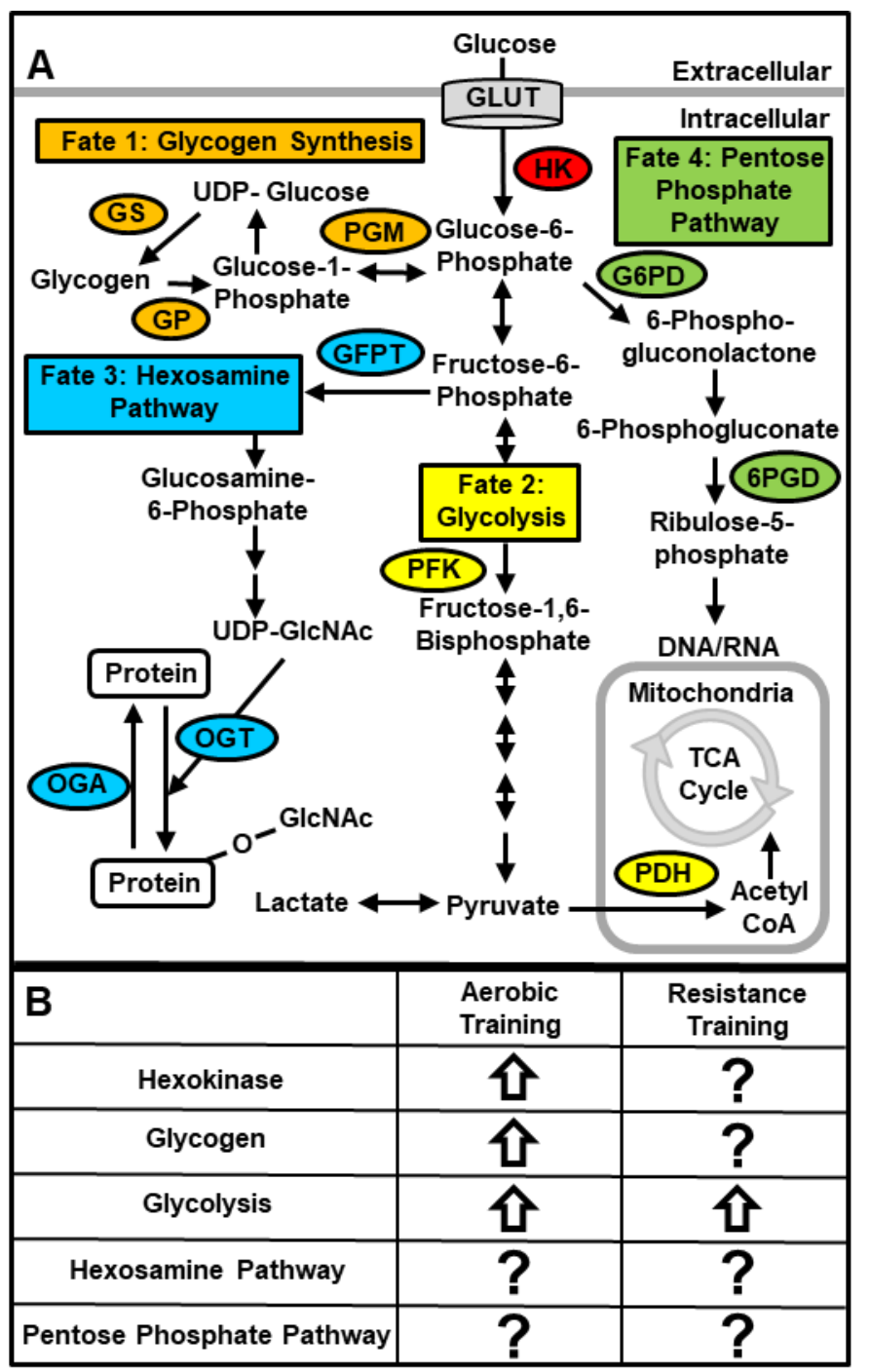

Figure 2. Major enzymes and metabolites of skeletal muscle glucose metabolism (A), and the effects of exercise training on the four major metabolic pathways (B). Key: 6PGD, 6-Phosphogluconate Dehydrogenase; G6PD, Glucose-6-Phosphate Dehydrogenase; GFPT, Glutamine-Fructose-6-Phosphate Transaminase; GP, Glycogen Phosphorylase; GS, Glycogen Synthase; HK, Hexokinase; OGA, O-GlcNAcase; OGT, O-GlcNAc Transferase; PFK, Phosphofructokinase; PGM, Phosphoglucomutase; $\mathrm{PDH}$, Pyruvate Dehydrogenase.

\subsection{Hexokinase}

Hexokinase is one of the most critical enzymes involved in skeletal muscle glucose metabolism, as the phosphorylation of glucose prevents it from diffusing back out of the cell. In resting mouse skeletal muscle, basal glucose uptake was not affected by an $~ 800 \%$ increase in hexokinase II protein levels demonstrating that hexokinase activity does not limit skeletal muscle glucose transport in the basal (non-insulin-stimulated) state [157]. Acute stimulation of skeletal muscle by insulin or exercise/contraction increases hexokinase activity in both human and rodent skeletal muscle [158-160]. In contrast to the basal state, hexokinase expression/activity regulates muscle glucose transport in response to insulin and exercise. In muscle-specific hexokinase II overexpression mice, muscle glucose transport in response to both hyperinsulinemia and an acute $10 \mathrm{~min}$ bout of treadmill running was increased $\sim 30-40 \%$ [157], suggesting that under stimulated conditions hexokinase activity controls the amount of muscle glucose transport. Consistent with those findings, in mice with a $50 \%$ reduction of hexokinase activity, soleus muscle glucose transport was decreased $\sim 70 \%$ following an acute $30 \mathrm{~min}$ 
bout of treadmill running [161]. However, in the gastrocnemius muscle of hexokinase knockdown mice neither insulin nor exercise-mediated glucose transport was altered [161,162]. Together these findings suggest that hexokinase can be a limiting factor to muscle glucose uptake, but only under conditions of extremely elevated muscle glucose transport.

Numerous studies have shown that aerobic exercise training increases hexokinase protein and activity levels $\sim 25-100 \%$ in both human and rodent skeletal muscle [163-172]. In contrast, the effects of resistance exercise training on muscle hexokinase levels is less clear. In the skeletal muscle of healthy men, one study demonstrated a $28 \%$ increase in hexokinase activity following 10 weeks of isokinetic strength training [173]; a second study demonstrated no change in hexokinase activity following 12 weeks of high intensity resistance training [174]; and a third study found a 40\% decrease in hexokinase activity following 24 weeks of high intensity progressive resistance training [175].

\subsection{Cellular Fates of Glucose in Skeletal Muscle}

\subsubsection{Glycogen}

Glycogen is the polysaccharide storage form of glucose in skeletal muscle. Glucose entering muscle is committed to storage as glycogen when glucose-6-phosphate is converted to glucose-1-phosphate by the enzyme, phosphoglucomutase. Further metabolism to UDP-glucose enables the enzyme glycogen synthase (GS) to generate the multi-branched glucose polymers that are characteristic of a glycogen particle. When cellular energy demands increase, glycogen can be degraded to glucose-1-phosphate by the enzyme glycogen phosphorylase (GP), and then ultimately metabolized via glycolysis to make adenosine triphosphate (ATP).

In non-stimulated skeletal muscle, glycogen levels are determined by the balance between glycogen synthesis and glycogen degradation. Consistent with this statement, in muscle-specific GS overexpression mice muscle glycogen levels are increased $400 \%$ [176]; while in muscle-specific GS1 knockout mice muscle glycogen levels are decreased $65 \%$ in the fasted state [177].

Aerobic exercise training is well-known to increase glycogen levels and glycogen synthesis rates in both human and rodent skeletal muscle. These studies demonstrated the following results: (1) 6 weeks of stair climb training (4 days/week, $45 \mathrm{~min} /$ day at $65 \% \mathrm{VO}_{2}$ max) increased muscle glycogen synthesis rates $\sim 100 \%$ [171,178,179]; (2) 7 weeks of voluntary wheel running increased glycogen levels $\sim 30 \%$ in triceps muscles from female Sprague Dawley rats [179]; (3) 10 weeks of progressive high intensity cycle ergometry training ( 3 days/week, $90-100 \% \mathrm{VO}_{2} \max , 4 \times 5$ min bouts up to $5 \times 5 \mathrm{~min}$ bouts) and progressive running ( 3 days/week at $30 \mathrm{~min} /$ day up to $40 \mathrm{~min} /$ day) increased glycogen levels $\sim 80 \%$ in vastus lateralis muscle [132]; (4) 12 weeks of indoor cycle training (60 min/day, 4 days/week at $75-90 \%$ max heart rate) increased glycogen levels $\sim 80 \%$ in vastus lateralis muscle $[171,178,179]$; (5) 20 weeks of cycle ergometer training ( 1 hour/day, 4 days/week at $75-90 \% \mathrm{VO}_{2}$ max) increased muscle glycogen levels $\sim 150 \%$ [180]; and (6) endurance trained cyclists have $~ 65 \%$ higher muscle glycogen content than untrained individuals $48-72$ hours after an exhaustive cycling bout [181]. Thus, together these results suggest that aerobic training-induced increases in muscle glycogen content occur to provide a greater capacity to fuel future muscle contractions [182,183].

Unlike aerobic training, the effects of resistance exercise training on muscle glycogen levels are more variable. In both men and women, the following effects have been reported: (1) 6 weeks of progressive free weight and weight machine training of the upper body ( 3 days/week, 4 exercises/day, 10 sets/week up to 32 sets/week of 10 repetitions/set at $60 \%$ of 1 repetition max for each exercise) did not alter glycogen content $[184,185]$; (2) 6 weeks of progressive weight machine training of the leg ( 3 days/week, 3 exercises/session, 10 repetitions at $50 \%$ of 1 repetition max up to $8-12$ repetitions at $70-80 \%$ max) increased muscle glycogen levels $~ 14 \%$ [151]; (3) 16 weeks of weight machine training involving arms and legs (3 days/week, 5 exercises/session, 8 repetitions progressing from $60-80 \%$ to $70-80 \%$ max) increased muscle glycogen levels $~ 30 \%$ [9]; (4) 16 weeks of progressive lower body pneumatic training (3 days/week, 2 exercises/session, progressing from $60-65 \%$ to $75-80 \%$ of 
1 repetition max up) increased muscle glycogen levels $~ 45 \%$ [9,106]; and (5) 20 weeks of resistance exercise training (2-3 days/week, 4 exercises/session, 3-5 sets/day of 8-10 repetitions) increased glycogen levels $\sim 20 \%$ in triceps brachii muscles [186]. In addition, the following results were demonstrated in rodent skeletal muscle after resistance exercise training: (1) 12 weeks of squat training (3 days/week, 10 repetitions at $75 \%$ of one repetition max) increased gastrocnemius muscle glycogen levels $40-50 \%$ in male Sprague-Dawley rats [152]; (2) 12 weeks of progressive weighted ladder climbing $\left(80^{\circ}\right.$ incline, 4-8 climbs/day, 3 days/week with a load of $75 \%$ body weight up to $100 \%$ body weight) increased muscle glycogen levels $950-3500 \%$ in female Wistar rats [12]; (3) 12 weeks of progressive weighted ladder climbing $\left(80^{\circ}\right.$ incline, 3-6 climbs/day, 4 days/week with a load of $10 \%$ body weight up to $200 \%$ body weight) increased muscle glycogen levels $20-45 \%$ in male Wistar rats [12,14]; and (4) 4 days of functional overload did not change soleus muscle glycogen levels in male Swiss albino mice [12]. Thus, taken together these data suggest that the type, duration, and intensity of the resistance training program are important factors in determining the effects of resistance training on skeletal muscle glycogen content.

\subsubsection{Glycolytic Flux}

Glucose transported into muscle enters glycolysis once fructose-6-phosphate is converted to fructose-1,6-bisphosphate by the enzyme phosphofructokinase (PFK). Fructose-1,6-bisphosphate then undergoes the multi-step, sequential conversion to pyruvate. Muscle pyruvate has two main fates: (1) reduction to lactate; or (2) oxidation to acetyl-CoA by pyruvate dehydrogenase (PDH), which is then further metabolized via the tricarboxylic acid (TCA) cycle. Complete oxidation of glucose through the TCA cycle and mitochondrial electron transport chain yields 36 molecules of ATP.

Glucose flux through glycolysis plays a critical role in regulating skeletal muscle contractile function. In humans, genetic loss of muscle PFK activity (known as Tarui disease or glycogen storage disease type 7) is characterized by increases in skeletal muscle glucose-6-phosphate levels ( 360-1740\%), fructose-6-phosphate levels ( $280-1500 \%)$, and muscle glycogen levels $(\sim 75-350 \%)$ in the resting state; along with impairments in exercise tolerance (i.e., shorter time to fatigue) [187]. This clinical profile is mimicked in muscle PFK knockout mice which increased muscle glucose-6-phosphate levels $(\sim 320 \%)$ and glycogen levels $(\sim 110 \%)$ at rest; along with decreased ATP levels $(\sim 50 \%)$ and a severely shortened time to fatigue $(<1.5 \mathrm{~min})$ when subjected to treadmill running [188]. Impairments in exercise endurance capacity were also observed in skeletal muscle specific-PDH $\alpha 1$ knockout mice [189], highlighting the importance of the ATP generated from complete glucose oxidation in muscle contraction and whole-body locomotion.

Aerobic exercise training results in variable changes in skeletal muscle glycolytic capacity. This is demonstrated in studies conducted in both humans and rodents that showed $0-120 \%$ increases in muscle PFK activity following aerobic training. These studies found: (1) 20 weeks of cycle ergometer training (4 days/week, 1 hour/day at $75-90 \% \mathrm{VO}_{2}$ max) increased PFK activity $\sim 120 \%$ in human vastus lateralis muscle [180](2) 6 weeks of treadmill running ( 5 days/week, 6 bouts of 4.5 min at $40 \mathrm{~m} / \mathrm{min}$ ) increased PFK activity 20-25\% in rat soleus and deep vastus lateralis muscle, but not in the superficial vastus lateralis or the diaphragm [190]; and (3) 16 weeks of voluntary wheel cage running increased PFK activity $\sim 87 \%$ in rat white gastrocnemius muscle [191], but did not alter it in the soleus, plantaris or red gastrocnemius [191]. In contrast, studies have demonstrated that aerobic training increases glucose oxidative capacity, as evidenced by the following findings: (1) 6 weeks of high intensity interval training ( 3 days/week, $10 \times 4$ min intervals/day at $\sim 90 \% \mathrm{VO}_{2}$ max, ) increased $\mathrm{PDH}$ activity $\sim 20 \%$ in human vastus lateralis muscle [136]; and that (2) 8 weeks of cycle ergometer training (5 days/week, 1 hour/day at $75 \% \mathrm{VO}_{2}$ max) increased $\mathrm{PDH}$ activity $~ 30 \%$ in human vastus lateralis [192].

Similar to aerobic training, resistance exercise training induces changes in skeletal muscle that favor an increase in the capacity of glucose flux through glycolysis. Studies performed in humans and rodents demonstrated the following findings: (1) 14 weeks of progressive free weight training of arms and shoulders (3 days/week, 3 exercises/session, 3 sets/exercise with increasing loads) increased PFK 
activity 20\% in human deltoid muscle [193]; (2) 24 weeks of progressive free weight squatting and jumping training did not alter PFK activity in human vastus lateralis muscle [175]; and (3) 10 weeks of isometric wire hang training (5 sessions/week, three 3-minute bouts/session) increased rectus femoris muscle PFK mRNA levels $\sim 320 \%$ in high fat diet-induced hyperglycemic C57BL/6N mice compared to sedentary controls [58]. In addition, in mouse soleus muscle, 4 days of functional overload increased 3-[ $\left[{ }^{3} \mathrm{H}\right]$-D-glucose conversion ${ }^{3} \mathrm{H}_{2} \mathrm{O} \sim 50 \%$ [17], a process that occurs during the enolase reaction. Thus, collectively, these findings suggest that both aerobic and resistance training increase the capacity of skeletal muscle to utilize glucose through glycolysis to generate ATP.

\subsubsection{Hexosamine Pathway}

The hexosamine pathway is a glucose utilizing pathway that is initiated when fructose-6-phosphate is converted to glucosamine-6-phosphate by the enzyme glutamine fructose-6-phosphate transaminase 1 (GFPT1). The hexosamine pathway produces UDP-N-acetylglucosamine and other nucleotide hexosamines which are used for the glycosylation, N-linked GlcNAcylation, and O-linked GlcNAcylation of proteins [reviewed in [194]]. Protein O-GlcNAcylation is one of the most commonly studied modifications of hexosamine pathway activity and is controlled by the following two enzymes: (1) O-GlcNAc transferase (OGT), which adds O-GlcNAc to proteins; and (2) O-GlcNAcase (OGA), which removes O-GlcNAc from proteins.

Multiple studies in both human and rodent muscle have linked increased hexosamine pathway activity to the development of muscle insulin resistance. In the vastus lateralis muscle of individuals with type 2 diabetes, O-GlcNAcylated protein levels were $~ 50 \%$ higher compared to lean, healthy controls [195]. In addition, while transgenic mice overexpressing GFPT1 exhibited a $\sim 50 \%$ reduction in insulin-stimulated muscle glucose disposal [196], muscle-specific OGT knockout mice exhibited enhanced insulin-stimulated muscle glucose transport [195]. Thus, collectively these studies demonstrate a direct positive relationship between activation of the hexosamine pathway and skeletal muscle insulin resistance.

Since aerobic and resistance exercise training are associated with enhancements in skeletal muscle insulin sensitivity and glucose transport, it could be postulated that exercise training would decrease hexosamine pathway activity. To date, only two studies have directly examined the effects of exercise training on the hexosamine pathway in skeletal muscle, and both examined the effects of aerobic training. In the vastus lateralis of postmenopausal women, one year of progressive plyometric training did not alter the mRNA levels of OGT or OGA compared to sedentary postmenopausal controls [197]. In contrast, six weeks of progressive treadmill running increased protein O-GlcNAcylation levels $\sim 80-100 \%$ in both the soleus and extensor digitorum longus muscles of male Sprague Dawley rats [198]. Taken together these results suggest that exercise training-mediated adaptations in the hexosamine pathway and protein O-GlcNAcylation levels in skeletal muscle may be gender and/or species specific. However, given the conflicting findings and limited amount of studies investigating this interaction, any current conclusions should be considered with caution. Additional studies are needed in humans and rodent models from both sexes to fully assess the possible role of the hexosamine pathway in training-induced alterations in muscle glucose transport and metabolism.

\subsubsection{Pentose Phosphate Pathway}

The pentose phosphate pathway is a glucose utilizing pathway that is initiated when glucose-6-phosphate is converted to 6-phosphogluconolactone by glucose-6-phosphate dehydrogenase (G6PD). It is used to make metabolites critical for skeletal muscle anabolism, including: (1) nicotinamide adenine dinucleotide phosphate (NADPH) for reductive biosynthesis reactions such as lipogenesis; (2) ribose 5-phosphate for nucleotide synthesis; and (3) erythrose-4-phosphate for aromatic amino acid synthesis. A second important enzyme in this pathway, 6-phosphogluconate dehydrogenase (6PGD), is responsible for the production of ribulose 5-phosphate from 6-phosphogluconate, and its activity is often measured to assess pentose phosphate pathway activity [199-201]. 
In non-stimulated skeletal muscle, the activity of the pentose phosphate pathway is low compared to most other tissues [202,203]. This finding is perhaps not surprising since skeletal muscle is a differentiated cell type, and at rest does not have the biosynthetic demands of proliferative cell types such as the liver. In contrast, studies have demonstrated an increase in the activity of the pentose phosphate pathway in skeletal muscle in response to damage/regeneration. In individuals with Duchenne's muscular dystrophy, a condition characterized by a cycle of skeletal muscle degeneration and regeneration, muscle G6PD activity is increased $\sim 400 \%$ and 6PGD activity $~ 300 \%$ compared to healthy age-matched controls [199]. In rat skeletal muscle, administration of the myotoxic agent Marcaine stimulated G6PD activity 350\% and 6PGD activity 140\% [200], while a muscle damaging bout of downhill running increased G6PD activity 100-350\% [204]. In addition, an acute bout of $10 \mathrm{~min}$ of high intensity tetanic contractions increased rat muscle ribose-5-phosphate levels [205]. Collectively these findings suggest that activation of the pentose phosphate pathway occurs in skeletal muscle to provide substrates for muscle repair processes.

The role of the pentose phosphate pathway in mediating either aerobic exercise training-induced or resistance exercise training-induced adaptations in skeletal muscle glucose metabolism has not yet been investigated. However, recent work utilizing transgenic mice expressing key signaling proteins involved in mediating exercise training-induced adaptations in muscle, such as the peroxisome proliferator-activated receptor gamma coactivator 1-alpha (PGC-1 $\alpha$ ) and Akt isoform 1 (Akt1), suggest an involvement of the pentose phosphate pathway in this process. PGC- $1 \alpha$ is a transcriptional co-activator found in skeletal muscle that plays a critical role in mediating aerobic exercise training-induced increases in mitochondrial biogenesis, substrate metabolism, and fiber type switching (reviewed in [206]). Intriguingly, in skeletal muscle of muscle-specific PGC-1 $\alpha$ overexpression mice there is an increase in key pentose phosphate pathway metabolites, including: 6-phosphogluconate, ribulose-5-phosphate, ribose-5-phosphate, NADPH, and sedoheptulose-7-phosphate [207]. Akt1 is a kinase found in skeletal muscle that plays a critical role in mediating resistance exercise training-induced muscle hypertrophic growth and protein synthesis (reviewed in $[208,209])$. In skeletal muscle of muscle-specific Akt1 overexpression mice there is also an increase in key pentose phosphate pathway metabolites and enzymes, including: ribose-5-phosphate, G6PD and 6PGD [201]. While taken together these results suggest that exercise training may stimulate glucose flux via the pentose phosphate pathway in skeletal muscle, additional studies examining skeletal muscle from exercise trained humans or rodents are needed to fully assess a role for this metabolic pathway in exercise training-induced adaptations in skeletal muscle glucose metabolism.

\section{Conclusions}

Both aerobic and resistance exercise training are beneficial in ameliorating the hyperglycemia associated with the metabolic disease, type 2 diabetes. This beneficial blood glucose lowering effect can be at least partially attributed to training-stimulated alterations in skeletal muscle glucose transport and glucose metabolism. This review of the current literature found that the effects of aerobic training are often larger in magnitude than those elicited by resistance training, and we speculate that this difference can be attributed to one or more of the following factors: (1) Duration of the training program; (2) intensity of the training; (3) prior training experience; (4) specific skeletal muscle examined; and/or (5) number of muscle groups stimulated by the exercise. In addition, throughout this review a number of key gaps in our current understanding of how both aerobic and resistance training alter skeletal muscle glucose transport and metabolism were identified. These key gaps included: (1) Mechanism underlying decreased exercise/contraction-stimulated glucose transport following aerobic training; (2) identity of the glucose transporter isoform(s) involved in mediating resistance training-stimulated muscle glucose transport; and (3) the exact proportion of glucose that enters each cellular fate in skeletal muscle in response to aerobic and resistance training. Future endeavors focused on determining the molecular and cellular factors that are responsible for the ability of exercise training to elicit beneficial 
effects on systemic glucose homeostasis, skeletal muscle glucose transport and/or skeletal muscle glucose metabolism should seek to fill in these critical knowledge gaps.

Author Contributions: Conceptualization of the topic, S.L.M., L.A.W., P.L.E., and C.A.W.; writing-original draft preparation, S.L.M., L.A.W., P.L.E., and C.A.W.; writing-review and editing, S.L.M., L.A.W., P.L.E., and C.A.W.; funding acquisition, S.L.M. and C.A.W.

Funding: This research was funded by the National Institutes of Health (Grant\#: R01DK103562; Grant\#: F31DK119080) and the American College of Sports Medicine (Grant\#: 18-00636). The APC was funded by the National Institutes of Health (Grant\#: R01DK103562).

Acknowledgments: We would like to thank William M. Taylor for his assistance in literature searches.

Conflicts of Interest: The authors declare no conflict of interest.

\section{References}

1. Church, T.S.; Blair, S.N.; Cocreham, S.; Johannsen, N.; Johnson, W.; Kramer, K.; Mikus, C.R.; Myers, V.; Nauta, M.; Rodarte, R.Q.; et al. Effects of Aerobic and Resistance Training on Hemoglobin A1c Levels in Patients with Type 2 Diabetes: A Randomized Controlled Trial. JAMA 2010, 304, 2253-2262. [CrossRef] [PubMed]

2. Jorge, M.L.M.P.; de Oliveira, V.N.; Resende, N.M.; Paraiso, L.F.; Calixto, A.; Diniz, A.L.D.; Resende, E.S.; Ropelle, E.R.; Carvalheira, J.B.; Espindola, F.S.; et al. The effects of aerobic, resistance, and combined exercise on metabolic control, inflammatory markers, adipocytokines, and muscle insulin signaling in patients with type 2 diabetes mellitus. Metabolism 2011, 60, 1244-1252. [CrossRef] [PubMed]

3. Karstoft, K.; Winding, K.; Knudsen, S.H.; Nielsen, J.S.; Thomsen, C.; Pedersen, B.K.; Solomon, T.P.J. The Effects of Free-Living Interval-Walking Training on Glycemic Control, Body Composition, and Physical Fitness in Type 2 Diabetic Patients: A randomized, controlled trial. Diabetes Care 2013, 36, 228-236. [CrossRef] [PubMed]

4. Sigal, R.J.; Kenny, G.P.; Boulé, N.G.; Wells, G.A.; Prud'homme, D.; Fortier, M.; Reid, R.D.; Tulloch, H.; Coyle, D.; Phillips, P.; et al. Effects of Aerobic Training, Resistance Training, or Both on Glycemic Control in Type 2 Diabetes: A Randomized TrialEffects of Aerobic and Resistance Training on Glycemic Control in Type 2 Diabetes. Ann. Intern. Med. 2007, 147, 357-369. [CrossRef] [PubMed]

5. Cortez, M.Y.; Torgan, C.E.; Brozinick, J.T.; Ivy, J.L. Insulin resistance of obese Zucker rats exercise trained at two different intensities. Am. J. Physiol. -Endocrinol. Metab. 1991, 261, E613-E619. [CrossRef] [PubMed]

6. Ghosh, S.; Khazaei, M.; Moien-Afshari, F.; Ang, L.S.; Granville, D.J.; Verchere, C.B.; Dunn, S.R.; McCue, P.; Mizisin, A.; Sharma, K.; et al. Moderate exercise attenuates caspase-3 activity, oxidative stress, and inhibits progression of diabetic renal disease in db/db mice. Am. Physiol. -Ren. Physiol. 2009, 296, F700-F708. [CrossRef]

7. Ward, K.M.; Mahan, J.D.; Sherman, W.M. Aerobic training and diabetic nephropathy in the obese Zucker rat. Ann. Clin. Lab. Sci. 1994, 24, 266-277.

8. Arora, E.; Shenoy, S.; Sandhu, J.S. Effects of resistance training on metabolic profile of adults with type 2 diabetes. Indian. J. Med. Res. 2009, 5, 515-519.

9. Castaneda, C.; Layne, J.E.; Munoz-Orians, L.; Gordon, P.L.; Walsmith, J.; Foldvari, M.; Roubenoff, R.; Tucker, K.L.; Nelson, M.E. A Randomized Controlled Trial of Resistance Exercise Training to Improve Glycemic Control in Older Adults With Type 2 Diabetes. Diabetes Care 2002, 25, 2335-2341. [CrossRef]

10. Dunstan, D.W.; Daly, R.M.; Owen, N.; Jolley, D.; de Courten, M.; Shaw, J.; Zimmet, P. High-Intensity Resistance Training Improves Glycemic Control in Older Patients With Type 2 Diabetes. Diabetes Care 2002, 25, 1729-1736. [CrossRef] [PubMed]

11. Kim, J.; Choi, M.J.; So, B.; Kim, H.; Seong, J.K.; Song, W. The Preventive Effects of 8 Weeks of Resistance Training on Glucose Tolerance and Muscle Fiber Type Composition in Zucker Rats. Diabetes Metab. J. 2015, 39, 424-433. [CrossRef] [PubMed]

12. Prestes, J.; Leite, R.D.; Pereira, G.B.; Shiguemoto, G.E.; Bernardes, C.F.; Asano, R.Y.; Sales, M.M.; Bartholomeu Neto, J.; Perez, S.E.A. Resistance Training and Glycogen Content in Ovariectomized Rats. Int. J. Sports. Med. 2012, 33, 550-554. [CrossRef] [PubMed] 
13. Quines, C.B.; Jardim, N.S.; Araujo, P.C.O.; Cechella, J.L.; Prado, V.C.; Nogueira, C.W. Resistance training restores metabolic alterations induced by monosodium glutamate in a sex-dependent manner in male and female rats. J. Cell. Biochem. 2019, 120, 13426-13440. [CrossRef] [PubMed]

14. Scheffer, D.L.; Silva, L.A.; Tromm, C.B.; da Rosa, G.L.; Silveira, P.C.L.; de Souza, C.T.; Latini, A.; Pinho, R.A. Impact of different resistance training protocols on muscular oxidative stress parameters. Appl. Physiol. Nutr. Metab. 2012, 37, 1239-1246. [CrossRef] [PubMed]

15. Goldberg, A. Work-induced growth of skeletal muscle in normal and hypophysectomized rats. Am. J. Physiol. -Leg. Content 1967, 213, 1193-1198. [CrossRef] [PubMed]

16. Armstrong, R.B.; Marum, P.; Tullson, P.; Saubert, C.W. Acute hypertrophic response of skeletal muscle to removal of synergists. J. Appl. Physiol. 1979, 46, 835-842. [CrossRef] [PubMed]

17. Augert, G.; Van de Werve, G.; Le Marchand-Brustel, Y. Effect of work-induced hypertrophy on muscle glucose metabolism in lean and obese mice. Diabetologia 1985, 28, 295-301. [CrossRef] [PubMed]

18. Baldwin, K.M.; Martinez, O.M.; Cheadle, W.G. Enzymatic changes in hypertrophied fast-twitch skeletal muscle. Pflugers Arch. 1976, 364, 229-234. [CrossRef]

19. Bodine, S.C.; Baar, K. Analysis of Skeletal Muscle Hypertrophy in Models of Increased Loading. In Myogenesis: Methods and Protocols; DiMario, J.X., Ed.; Methods in Molecular Biology; Humana Press: Totowa, NJ, USA, 2012; pp. 213-229. ISBN 978-1-61779-343-1.

20. Ferey, J.L.A.; Brault, J.J.; Smith, C.A.S.; Witczak, C.A. Constitutive activation of CaMKK $\alpha$ signaling is sufficient but not necessary for mTORC1 activation and growth in mouse skeletal muscle. Am. J. Physiol. -Endocrinol. Metab. 2014, 307, E686-E694. [CrossRef]

21. Johnson, T.L.; Klueber, K.M. Skeletal muscle following tonic overload: Functional and structural analysis. Med. Sci. Sports Exerc. 1991, 23, 49. [CrossRef]

22. Larkin, L.M.; Kuzon, W.M.; Halter, J.B. Synergist muscle ablation and recovery from nerve-repair grafting: Contractile and metabolic function. J. Appl. Physiol. 2000, 89, 1469-1476. [CrossRef] [PubMed]

23. Sitnick, M.; Bodine, S.C.; Rutledge, J.C. Chronic high fat feeding attenuates load-induced hypertrophy in mice. J. Physiol. 2009, 587, 5753-5765. [CrossRef] [PubMed]

24. Matsuo, T.; Saotome, K.; Seino, S.; Shimojo, N.; Matsushita, A.; Iemitsu, M.; Ohshima, H.; Tanaka, K.; Mukai, C. Effects of a low-volume aerobic-type interval exercise on VO2max and cardiac mass. Med. Sci. Sports Exerc. 2014, 46, 42-50. [CrossRef] [PubMed]

25. Levy, W.C.; Cerqueira, M.D.; Harp, G.D.; Johannessen, K.-A.; Abrass, I.B.; Schwartz, R.S.; Stratton, J.R. Effect of endurance exercise training on heart rate variability at rest in healthy young and older men. Am. J. Cardiol. 1998, 82, 1236-1241. [CrossRef]

26. Cornelissen, V.A.; Verheyden, B.; Aubert, A.E.; Fagard, R.H. Effects of aerobic training intensity on resting, exercise and post-exercise blood pressure, heart rate and heart-rate variability. J. Hum. Hypertens. 2010, 24, 175-182. [CrossRef] [PubMed]

27. Katch, V.L.; Sady, S.S.; Freedson, P. Biological variability in maximum aerobic power. Med. Sci. Sports Exerc. 1982, 14, 21-25. [CrossRef] [PubMed]

28. Solomon, T.P.J.; Malin, S.K.; Karstoft, K.; Knudsen, S.H.; Haus, J.M.; Laye, M.J.; Kirwan, J.P. Association Between Cardiorespiratory Fitness and the Determinants of Glycemic Control Across the Entire Glucose Tolerance Continuum. Diabetes Care 2015, 38, 921-929. [CrossRef] [PubMed]

29. Phillips, S.M. Short-Term Training: When Do Repeated Bouts of Resistance Exercise Become Training? Can. J. Appl. Physiol. 2000, 25, 185-193. [CrossRef]

30. Toigo, M.; Boutellier, U. New fundamental resistance exercise determinants of molecular and cellular muscle adaptations. Eur. J. Appl. Physiol. 2006, 97, 643-663. [CrossRef]

31. Schoenfeld, B.J. The Mechanisms of Muscle Hypertrophy and Their Application to Resistance Training. J. Strength Cond. Res. 2010, 24, 2857. [CrossRef]

32. Treuth, M.S.; Ryan, A.S.; Pratley, R.E.; Rubin, M.A.; Miller, J.P.; Nicklas, B.J.; Sorkin, J.; Harman, S.M.; Goldberg, A.P.; Hurley, B.F. Effects of strength training on total and regional body composition in older men. J. Appl. Physiol. 1994, 77, 614-620. [CrossRef] [PubMed]

33. Duplanty, A.A.; Levitt, D.E.; Hill, D.W.; McFarlin, B.K.; DiMarco, N.M.; Vingren, J.L. Resistance Training Is Associated With Higher Bone Mineral Density Among Young Adult Male Distance Runners Independent of Physiological Factors. J. Strength Cond. Res. 2018, 32, 1594-1600. [CrossRef] [PubMed] 
34. English, K.L.; Loehr, J.A.; Lee, S.M.; Smith, S.M. Early-phase musculoskeletal adaptations to different levels of eccentric resistance after 8 weeks of lower body training. Eur. J. Appl. Physiol. 2014, 114, 2263-2280. [CrossRef] [PubMed]

35. Braith, R.W.; Beck, D.T. Resistance exercise: Training adaptations and developing a safe exercise prescription. Heart Fail Rev. 2008, 13, 69-79. [CrossRef] [PubMed]

36. Association, A.D. 2. Classification and Diagnosis of Diabetes: Standards of Medical Care in Diabetes-2019. Diabetes Care 2019, 42, S13-S28. [CrossRef] [PubMed]

37. Dimitriadis, G.; Mitrou, P.; Lambadiari, V.; Maratou, E.; Raptis, S.A. Insulin effects in muscle and adipose tissue. Diabetes Res. Clin. Pract. 2011, 93, S52-S59. [CrossRef]

38. Han, H.-S.; Kang, G.; Kim, J.S.; Choi, B.H.; Koo, S.-H. Regulation of glucose metabolism from a liver-centric perspective. Exp. Mol. Med. 2016, 48, e218. [CrossRef] [PubMed]

39. MacDonald Patrick E; Joseph Jamie W; Rorsman Patrik Glucose-sensing mechanisms in pancreatic $\beta$-cells. Philos. Trans. R. Soc. B: Biol. Sci. 2005, 360, 2211-2225. [CrossRef]

40. DeFronzo, R.A.; Ferrannini, E.; Simonson, D.C. Fasting hyperglycemia in non-insulin-dependent diabetes mellitus: Contributions of excessive hepatic glucose production and impaired tissue glucose uptake. Metabolism 1989, 38, 387-395. [CrossRef]

41. Garvey, W.T.; Maianu, L.; Huecksteadt, T.P.; Birnbaum, M.J.; Molina, J.M.; Ciaraldi, T.P. Pretranslational suppression of a glucose transporter protein causes insulin resistance in adipocytes from patients with non-insulin-dependent diabetes mellitus and obesity. J. Clin. Investig. 1991, 87, 1072-1081. [CrossRef]

42. Kahn, B.B.; Charron, M.J.; Lodish, H.F.; Cushman, S.W.; Flier, J.S. Differential regulation of two glucose transporters in adipose cells from diabetic and insulin-treated diabetic rats. J. Clin. Investig. 1989, 84, 404-411. [CrossRef] [PubMed]

43. Wallberg-Henriksson, H. Glucose transport into skeletal muscle. Influence of contractile activity, insulin, catecholamines and diabetes mellitus. Acta Physiol. Scand. Suppl. 1987, 564, 1-80. [PubMed]

44. Zierath, J. In vitro studies of human skeletal muscle: Hormonal and metabolic regulation of glucose transport. Acta Physiol. Scand. Suppl. 1995, 626, 1-96. [PubMed]

45. Stumvoll, M.; Goldstein, B.J.; van Haeften, T.W. Type 2 diabetes: Principles of pathogenesis and therapy. Lancet 2005, 365, 1333-1346. [CrossRef]

46. Vijan, S. Type 2 Diabetes. Ann. Intern. Med. 2010, 152, ITC3-1. [CrossRef] [PubMed]

47. Zaccardi, F.; Webb, D.R.; Yates, T.; Davies, M.J. Pathophysiology of type 1 and type 2 diabetes mellitus: A 90-year perspective. Postgrad. Med J. 2016, 92, 63-69. [CrossRef] [PubMed]

48. Bacchi, E.; Negri, C.; Zanolin, M.E.; Milanese, C.; Faccioli, N.; Trombetta, M.; Zoppini, G.; Cevese, A.; Bonadonna, R.C.; Schena, F.; et al. Metabolic Effects of Aerobic Training and Resistance Training in Type 2 Diabetic Subjects. Diabetes Care 2012, 35, 676. [CrossRef] [PubMed]

49. Kadoglou, N.P.E.; Fotiadis, G.; Kapelouzou, A.; Kostakis, A.; Liapis, C.D.; Vrabas, I.S. The differential anti-inflammatory effects of exercise modalities and their association with early carotid atherosclerosis progression in patients with Type 2 diabetes. Diabetic Med. 2013, 30, e41-e50. [CrossRef] [PubMed]

50. Yavari, A.; Najafipoor, F.; Aliasgharzadeh, A.; Niafar, M.; Mobasseri, M. Effect of aerobic exercise, resistance training or combined training on glycaemic control and cardiovascular risk factors in patients with type 2 diabetes. Biol. Sport 2012, 29, 135-143. [CrossRef]

51. Najafipour, F.; Mobasseri, M.; Yavari, A.; Nadrian, H.; Aliasgarzadeh, A.; Abbasi, N.M.; Niafar, M.; Gharamaleki, J.H.; Sadra, V. Effect of regular exercise training on changes in HbA1c, BMI and VO2max among patients with type 2 diabetes mellitus: An 8-year trial. BMJ Open Diabetes Res. Care 2017, 5, e000414. [CrossRef]

52. Sennott, J.; Morrissey, J.; Standley, P.R.; Broderick, T.L. Treadmill exercise training fails to reverse defects in glucose, insulin and muscle GLUT4 content in the $\mathrm{db} / \mathrm{db}$ mouse model of diabetes. Pathophysiology 2008, 15, 173-179. [CrossRef] [PubMed]

53. De Lemos, E.T.; Reis, F.; Baptista, S.; Pinto, R.; Sepodes, B.; Vala, H.; Rocha-Pereira, P.; Silva, A.S.; Teixeira, F. Exercise training is associated with improved levels of C-reactive protein and adiponectin in ZDF (type 2) diabetic rats. Med. Sci. Monit. 2007, 13, BR168-BR174. [PubMed] 
54. Teixeira de Lemos, E.; Pinto, R.; Oliveira, J.; Garrido, P.; Sereno, J.; Mascarenhas-Melo, F.; Páscoa-Pinheiro, J.; Teixeira, F.; Reis, F. Differential Effects of Acute (Extenuating) and Chronic (Training) Exercise on Inflammation and Oxidative Stress Status in an Animal Model of Type 2 Diabetes Mellitus. Available online: https: //www.hindawi.com/journals/mi/2011/253061/abs/ (accessed on 5 September 2019).

55. Király, M.A.; Bates, H.E.; Kaniuk, N.A.; Yue, J.T.Y.; Brumell, J.H.; Matthews, S.G.; Riddell, M.C.; Vranic, M. Swim training prevents hyperglycemia in ZDF rats: Mechanisms involved in the partial maintenance of $\beta$-cell function. Am. J. Physiol. -Endocrinol. Metab. 2008, 294, E271-E283. [CrossRef] [PubMed]

56. Cauza, E.; Hanusch-Enserer, U.; Strasser, B.; Ludvik, B.; Metz-Schimmerl, S.; Pacini, G.; Wagner, O.; Georg, P.; Prager, R.; Kostner, K.; et al. The Relative Benefits of Endurance and Strength Training on the Metabolic Factors and Muscle Function of People With Type 2 Diabetes Mellitus. Arch. of Phys. Med. Rehabil. 2005, 86, 1527-1533. [CrossRef] [PubMed]

57. Hangping, Z.; Xiaona, Q.; Qi, Z.; Qingchun, L.; Na, Y.; Lijin, J.; Siying, L.; Shuo, Z.; Xiaoming, Z.; Xiaoxia, L.; et al. The impact on glycemic control through progressive resistance training with bioDensityTM in Chinese elderly patients with type 2 diabetes: The PReTTy2 (Progressive Resistance Training in Type 2 Diabetes) Trial. Diabetes Res. Clin. Pract. 2019, 150, 64-71. [CrossRef] [PubMed]

58. Krüger, K.; Gessner, D.K.; Seimetz, M.; Banisch, J.; Ringseis, R.; Eder, K.; Weissmann, N.; Mooren, F.C. Functional and Muscular Adaptations in an Experimental Model for Isometric Strength Training in Mice. PLoS ONE 2013, 8, e79069. [CrossRef]

59. DeFronzo, R.A.; Ferrannini, E.; Sato, Y.; Felig, P.; Wahren, J. Synergistic interaction between exercise and insulin on peripheral glucose uptake. J. Clin. Investig. 1981, 68, 1468-1474. [CrossRef]

60. Baron, A.D.; Brechtel, G.; Wallace, P.; Edelman, S.V. Rates and tissue sites of non-insulin- and insulin-mediated glucose uptake in humans. Am. J. Physiol. 1988, 255, E769-E774. [CrossRef]

61. Mueckler, M. Family of glucose-transporter genes. Implications for glucose homeostasis and diabetes. Diabetes 1990, 39, 6-11. [CrossRef]

62. Mueckler, M.; Thorens, B. The SLC2 (GLUT) family of membrane transporters. Mol. Aspects Med. 2013, 34, 121-138. [CrossRef]

63. Cura, A.J.; Carruthers, A. Role of monosaccharide transport proteins in carbohydrate assimilation, distribution, metabolism, and homeostasis. Compr. Physiol. 2012, 2, 863-914. [PubMed]

64. Zhao, F.-Q.; Keating, A.F. Functional properties and genomics of glucose transporters. Curr. Genomics 2007, 8, 113-128. [CrossRef] [PubMed]

65. Scheepers, A.; Joost, H.-G.; Schürmann, A. The glucose transporter families SGLT and GLUT: Molecular basis of normal and aberrant function. JPEN J Parenter Enter. Nutr. 2004, 28, 364-371. [CrossRef] [PubMed]

66. Deng, D.; Yan, N. GLUT, SGLT, and SWEET: Structural and mechanistic investigations of the glucose transporters. Protein Sci. 2016, 25, 546-558. [CrossRef] [PubMed]

67. Augustin, R. The protein family of glucose transport facilitators: It's not only about glucose after all. IUBMB Life 2010, 62, 315-333. [CrossRef] [PubMed]

68. Wright, E.M.; Loo, D.D.F.; Hirayama, B.A. Biology of human sodium glucose transporters. Physiol. Rev. 2011, 91, 733-794. [CrossRef] [PubMed]

69. Miele, C.; Formisano, P.; Condorelli, G.; Caruso, M.; Oriente, F.; Andreozzi, F.; Tocchetti, C.G.; Riccardi, G.; Beguinot, F. Abnormal glucose transport and GLUT1 cell-surface content in fibroblasts and skeletal muscle from NIDDM and obese subjects. Diabetologia 1997, 40, 421-429. [CrossRef] [PubMed]

70. Al-Khalili, L.; Chibalin, A.V.; Kannisto, K.; Zhang, B.B.; Permert, J.; Holman, G.D.; Ehrenborg, E.; Ding, V.D.H.; Zierath, J.R.; Krook, A. Insulin action in cultured human skeletal muscle cells during differentiation: Assessment of cell surface GLUT4 and GLUT1 content. Cell. Mol. Life Sci. 2003, 60, 991-998. [CrossRef]

71. Janot, M.; Audfray, A.; Loriol, C.; Germot, A.; Maftah, A.; Dupuy, F. Glycogenome expression dynamics during mouse $\mathrm{C} 2 \mathrm{C} 12$ myoblast differentiation suggests a sequential reorganization of membrane glycoconjugates. BMC Genomics 2009, 10, 483. [CrossRef]

72. Niu, W.; Bilan, P.J.; Ishikura, S.; Schertzer, J.D.; Contreras-Ferrat, A.; Fu, Z.; Liu, J.; Boguslavsky, S.; Foley, K.P.; Liu, Z.; et al. Contraction-related stimuli regulate GLUT4 traffic in C2C12-GLUT4myc skeletal muscle cells. Am. J. Physiol. Endocrinol. Metab. 2010, 298, E1058-E1071. [CrossRef]

73. McMillin, S.L.; Schmidt, D.L.; Kahn, B.B.; Witczak, C.A. GLUT4 Is Not Necessary for Overload-Induced Glucose Uptake or Hypertrophic Growth in Mouse Skeletal Muscle. Diabetes 2017, 66, 1491-1500. [CrossRef] [PubMed] 
74. Wang, W.; Hansen, P.A.; Marshall, B.A.; Holloszy, J.O.; Mueckler, M. Insulin unmasks a COOH-terminal Glut4 epitope and increases glucose transport across T-tubules in skeletal muscle. J. Cell Biol. 1996, 135, 415-430. [CrossRef] [PubMed]

75. Andrisse, S.; Patel, G.D.; Chen, J.E.; Webber, A.M.; Spears, L.D.; Koehler, R.M.; Robinson-Hill, R.M.; Ching, J.K.; Jeong, I.; Fisher, J.S. ATM and GLUT1-S490 phosphorylation regulate GLUT1 mediated transport in skeletal muscle. PLoS ONE 2013, 8, e66027. [CrossRef] [PubMed]

76. Marette, A.; Richardson, J.M.; Ramlal, T.; Balon, T.W.; Vranic, M.; Pessin, J.E.; Klip, A. Abundance, localization, and insulin-induced translocation of glucose transporters in red and white muscle. Am. J. Physiol. 1992, 263, C443-C452. [CrossRef] [PubMed]

77. Handberg, A.; Kayser, L.; Høyer, P.E.; Vinten, J. A substantial part of GLUT-1 in crude membranes from muscle originates from perineurial sheaths. Am. J. Physiol. 1992, 262, E721-E727. [CrossRef]

78. Yano, H.; Seino, Y.; Inagaki, N.; Hinokio, Y.; Yamamoto, T.; Yasuda, K.; Masuda, K.; Someya, Y.; Imura, H. Tissue distribution and species difference of the brain type glucose transporter (GLUT3). Biochem. Biophys. Res. Commun. 1991, 174, 470-477. [CrossRef]

79. Stuart, C.A.; Wen, G.; Jiang, J. GLUT3 protein and mRNA in autopsy muscle specimens. Metab. Clin. Exp. 1999, 48, 876-880. [CrossRef]

80. Haren, M.T.; Siddiqui, A.M.; Armbrecht, H.J.; Kevorkian, R.T.; Kim, M.J.; Haas, M.J.; Mazza, A.; Kumar, V.B.; Green, M.; Banks, W.A.; et al. Testosterone modulates gene expression pathways regulating nutrient accumulation, glucose metabolism and protein turnover in mouse skeletal muscle. Int. J. Androl. 2011, 34, 55-68. [CrossRef]

81. Bilan, P.J.; Mitsumoto, Y.; Maher, F.; Simpson, I.A.; Klip, A. Detection of the GLUT3 facilitative glucose transporter in rat L6 muscle cells: Regulation by cellular differentiation, insulin and insulin-like growth factor-I. Biochem. Biophys. Res. Commun. 1992, 186, 1129-1137. [CrossRef]

82. Teixeira, S.S.; Tamrakar, A.K.; Goulart-Silva, F.; Serrano-Nascimento, C.; Klip, A.; Nunes, M.T. Triiodothyronine acutely stimulates glucose transport into L6 muscle cells without increasing surface GLUT4, GLUT1, or GLUT3. Thyroid 2012, 22, 747-754. [CrossRef]

83. Guillet-Deniau, I.; Leturque, A.; Girard, J. Expression and cellular localization of glucose transporters (GLUT1, GLUT3, GLUT4) during differentiation of myogenic cells isolated from rat foetuses. J. Cell. Sci. 1994, 107 Pt 3, 487-496.

84. Shepherd, P.R.; Gould, G.W.; Colville, C.A.; McCoid, S.C.; Gibbs, E.M.; Kahn, B.B. Distribution of GLUT3 glucose transporter protein in human tissues. Biochem. Biophys. Res. Commun. 1992, 188, 149-154. [CrossRef]

85. Gumà, A.; Zierath, J.R.; Wallberg-Henriksson, H.; Klip, A. Insulin induces translocation of GLUT-4 glucose transporters in human skeletal muscle. Am. J. Physiol. 1995, 268, E613-E622. [CrossRef] [PubMed]

86. Kraegen, E.W.; Sowden, J.A.; Halstead, M.B.; Clark, P.W.; Rodnick, K.J.; Chisholm, D.J.; James, D.E. Glucose transporters and in vivo glucose uptake in skeletal and cardiac muscle: Fasting, insulin stimulation and immunoisolation studies of GLUT1 and GLUT4. Biochem. J. 1993, 295, 287-293. [CrossRef] [PubMed]

87. Zisman, A.; Peroni, O.D.; Abel, E.D.; Michael, M.D.; Mauvais-Jarvis, F.; Lowell, B.B.; Wojtaszewski, J.F.; Hirshman, M.F.; Virkamaki, A.; Goodyear, L.J.; et al. Targeted disruption of the glucose transporter 4 selectively in muscle causes insulin resistance and glucose intolerance. Nat. Med. 2000, 6, 924-928. [CrossRef] [PubMed]

88. Brozinick, J.T.; Etgen, G.J.; Yaspelkis, B.B.; Kang, H.Y.; Ivy, J.L. Effects of exercise training on muscle GLUT-4 protein content and translocation in obese Zucker rats. Am. J. Physiol. 1993, 265, E419-E427. [CrossRef] [PubMed]

89. Ploug, T.; van Deurs, B.; Ai, H.; Cushman, S.W.; Ralston, E. Analysis of GLUT4 distribution in whole skeletal muscle fibers: Identification of distinct storage compartments that are recruited by insulin and muscle contractions. J. Cell Biol. 1998, 142, 1429-1446. [CrossRef] [PubMed]

90. Hundal, H.S.; Darakhshan, F.; Kristiansen, S.; Blakemore, S.J.; Richter, E.A. GLUT5 expression and fructose transport in human skeletal muscle. Adv. Exp. Med. Biol. 1998, 441, 35-45.

91. Kristiansen, S.; Darakhshan, F.; Richter, E.A.; Hundal, H.S. Fructose transport and GLUT-5 protein in human sarcolemmal vesicles. Am. J. Physiol. 1997, 273, E543-E548. [CrossRef]

92. Ryder, J.W.; Kawano, Y.; Chibalin, A.V.; Rincón, J.; Tsao, T.S.; Stenbit, A.E.; Combatsiaris, T.; Yang, J.; Holman, G.D.; Charron, M.J.; et al. In vitro analysis of the glucose-transport system in GLUT4-null skeletal muscle. Biochem. J. 1999, 342 Pt 2, 321-328. [CrossRef] 
93. Hajduch, E.; Litherland, G.J.; Turban, S.; Brot-Laroche, E.; Hundal, H.S. Insulin regulates the expression of the GLUT5 transporter in L6 skeletal muscle cells. FEBS Lett. 2003, 549, 77-82. [CrossRef]

94. Darakhshan, F.; Hajduch, E.; Kristiansen, S.; Richter, E.A.; Hundal, H.S. Biochemical and functional characterization of the GLUT5 fructose transporter in rat skeletal muscle. Biochem. J. 1998, 336 Pt 2, 361-366. [CrossRef]

95. Chaillou, T.; Lee, J.D.; England, J.H.; Esser, K.A.; McCarthy, J.J. Time course of gene expression during mouse skeletal muscle hypertrophy. J. Appl. Physiol. 2013, 115, 1065-1074. [CrossRef] [PubMed]

96. Doege, H.; Schürmann, A.; Bahrenberg, G.; Brauers, A.; Joost, H.G. GLUT8, a novel member of the sugar transport facilitator family with glucose transport activity. J. Biol. Chem. 2000, 275, 16275-16280. [CrossRef] [PubMed]

97. Dawson, P.A.; Mychaleckyj, J.C.; Fossey, S.C.; Mihic, S.J.; Craddock, A.L.; Bowden, D.W. Sequence and functional analysis of GLUT10: A glucose transporter in the Type 2 diabetes-linked region of chromosome 20q12-13.1. Mol. Genet. Metab. 2001, 74, 186-199. [CrossRef] [PubMed]

98. Gaster, M.; Handberg, A.; Schürmann, A.; Joost, H.-G.; Beck-Nielsen, H.; Schrøder, H.D. GLUT11, but not GLUT8 or GLUT12, is expressed in human skeletal muscle in a fibre type-specific pattern. Pflugers Arch. 2004, 448, 105-113. [CrossRef] [PubMed]

99. Rogers, S.; Macheda, M.L.; Docherty, S.E.; Carty, M.D.; Henderson, M.A.; Soeller, W.C.; Gibbs, E.M.; James, D.E.; Best, J.D. Identification of a novel glucose transporter-like protein-GLUT-12. Am. J. Physiol. Endocrinol. Metab. 2002, 282, E733-E738. [CrossRef]

100. Stuart, C.A.; Yin, D.; Howell, M.E.A.; Dykes, R.J.; Laffan, J.J.; Ferrando, A.A. Hexose transporter mRNAs for GLUT4, GLUT5, and GLUT12 predominate in human muscle. Am. J. Physiol. Endocrinol. Metab. 2006, 291, E1067-E1073. [CrossRef]

101. Shaheen, F.; Grammatopoulos, D.K.; Müller, J.; Zammit, V.A.; Lehnert, H. Extra-nuclear telomerase reverse transcriptase (TERT) regulates glucose transport in skeletal muscle cells. Biochim. Biophys. Acta 2014, 1842, 1762-1769. [CrossRef]

102. Purcell, S.H.; Aerni-Flessner, L.B.; Willcockson, A.R.; Diggs-Andrews, K.A.; Fisher, S.J.; Moley, K.H. Improved insulin sensitivity by GLUT12 overexpression in mice. Diabetes 2011, 60, 1478-1482. [CrossRef]

103. Macheda, M.L.; Kelly, D.J.; Best, J.D.; Rogers, S. Expression during rat fetal development of GLUT12-a member of the class III hexose transporter family. Anat. Embryol. 2002, 205, 441-452. [CrossRef] [PubMed]

104. Chen, J.; Williams, S.; Ho, S.; Loraine, H.; Hagan, D.; Whaley, J.M.; Feder, J.N. Quantitative PCR tissue expression profiling of the human SGLT2 gene and related family members. Diabetes Ther 2010, 1, 57-92. [CrossRef] [PubMed]

105. Nagai, K.; Yoshida, S.; Konishi, H. Gender differences in the gene expression profiles of glucose transporter GLUT class I and SGLT in mouse tissues. Pharmazie 2014, 69, 856-859. [PubMed]

106. Castaneda, F.; Layne, J.E.; Castaneda, C. Skeletal muscle sodium glucose co-transporters in older adults with type 2 diabetes undergoing resistance training. Int. J. Med. Sci. 2006, 3, 84-91. [CrossRef] [PubMed]

107. Díez-Sampedro, A.; Hirayama, B.A.; Osswald, C.; Gorboulev, V.; Baumgarten, K.; Volk, C.; Wright, E.M.; Koepsell, H. A glucose sensor hiding in a family of transporters. Proc. Natl. Acad. Sci. USA 2003, 100, 11753-11758. [CrossRef]

108. Marshall, B.A.; Ren, J.M.; Johnson, D.W.; Gibbs, E.M.; Lillquist, J.S.; Soeller, W.C.; Holloszy, J.O.; Mueckler, M. Germline manipulation of glucose homeostasis via alteration of glucose transporter levels in skeletal muscle. J. Biol. Chem. 1993, 268, 18442-18445.

109. Hansen, P.A.; Wang, W.; Marshall, B.A.; Holloszy, J.O.; Mueckler, M. Dissociation of GLUT4 translocation and insulin-stimulated glucose transport in transgenic mice overexpressing GLUT1 in skeletal muscle. J. Biol. Chem. 1998, 273, 18173-18179. [CrossRef]

110. Deshmukh, A.S.; Murgia, M.; Nagaraj, N.; Treebak, J.T.; Cox, J.; Mann, M. Deep proteomics of mouse skeletal muscle enables quantitation of protein isoforms, metabolic pathways, and transcription factors. Mol. Cell Proteom. 2015, 14, 841-853. [CrossRef]

111. Jaldin-Fincati, J.R.; Pavarotti, M.; Frendo-Cumbo, S.; Bilan, P.J.; Klip, A. Update on GLUT4 Vesicle Traffic: A Cornerstone of Insulin Action. Trends Endocrinol. Metab. 2017, 28, 597-611. [CrossRef]

112. Foley, K.; Boguslavsky, S.; Klip, A. Endocytosis, recycling, and regulated exocytosis of glucose transporter 4. Biochemistry 2011, 50, 3048-3061. [CrossRef] 
113. Douen, A.G.; Ramlal, T.; Rastogi, S.; Bilan, P.J.; Cartee, G.D.; Vranic, M.; Holloszy, J.O.; Klip, A. Exercise induces recruitment of the "insulin-responsive glucose transporter". Evidence for distinct intracellular insulin- and exercise-recruitable transporter pools in skeletal muscle. J. Biol. Chem. 1990, 265, 13427-13430. [PubMed]

114. Whitfield, J.; Paglialunga, S.; Smith, B.K.; Miotto, P.M.; Simnett, G.; Robson, H.L.; Jain, S.S.; Herbst, E.A.F.; Desjardins, E.M.; Dyck, D.J.; et al. Ablating the protein TBC1D1 impairs contraction-induced sarcolemmal glucose transporter 4 redistribution but not insulin-mediated responses in rats. J. Biol. Chem. 2017, 292, 16653-16664. [CrossRef] [PubMed]

115. Klip, A.; McGraw, T.E.; James, D.E. 30 sweet years of GLUT4. J. Biol. Chem. 2019, 30, 11369-11381. [CrossRef] [PubMed]

116. Lauritzen, H.P.M.M. Insulin- and contraction-induced glucose transporter 4 traffic in muscle: Insights from a novel imaging approach. Exerc. Sport Sci. Rev. 2013, 41, 77-86. [CrossRef] [PubMed]

117. Huang, S.; Czech, M.P. The GLUT4 glucose transporter. Cell Metab. 2007, 5, 237-252. [CrossRef] [PubMed]

118. Bryant, N.J.; Govers, R.; James, D.E. Regulated transport of the glucose transporter GLUT4. Nat. Rev. Mol. Cell Biol. 2002, 3, 267-277. [CrossRef] [PubMed]

119. Lauritzen, H.P.M.M. In vivo imaging of GLUT4 translocation. Appl. Physiol. Nutr. Metab. 2009, 34, 420-423. [CrossRef] [PubMed]

120. Ryder, J.W.; Yang, J.; Galuska, D.; Rincón, J.; Björnholm, M.; Krook, A.; Lund, S.; Pedersen, O.; Wallberg-Henriksson, H.; Zierath, J.R.; et al. Use of a novel impermeable biotinylated photolabeling reagent to assess insulin- and hypoxia-stimulated cell surface GLUT4 content in skeletal muscle from type 2 diabetic patients. Diabetes 2000, 49, 647-654. [CrossRef]

121. Zierath, J.R.; He, L.; Gumà, A.; Odegoard Wahlström, E.; Klip, A.; Wallberg-Henriksson, H. Insulin action on glucose transport and plasma membrane GLUT4 content in skeletal muscle from patients with NIDDM. Diabetologia 1996, 39, 1180-1189. [CrossRef]

122. Garvey, W.T.; Maianu, L.; Zhu, J.H.; Brechtel-Hook, G.; Wallace, P.; Baron, A.D. Evidence for defects in the trafficking and translocation of GLUT4 glucose transporters in skeletal muscle as a cause of human insulin resistance. J. Clin. Investig. 1998, 101, 2377-2386. [CrossRef]

123. Shepherd, P.R.; Kahn, B.B. Glucose transporters and insulin action-implications for insulin resistance and diabetes mellitus. N. Engl. J. Med. 1999, 341, 248-257. [CrossRef] [PubMed]

124. Jessen, N.; Goodyear, L.J. Contraction signaling to glucose transport in skeletal muscle. J. Appl. Physiol. 2005, 99, 330-337. [CrossRef] [PubMed]

125. Kennedy, J.W.; Hirshman, M.F.; Gervino, E.V.; Ocel, J.V.; Forse, R.A.; Hoenig, S.J.; Aronson, D.; Goodyear, L.J.; Horton, E.S. Acute exercise induces GLUT4 translocation in skeletal muscle of normal human subjects and subjects with type 2 diabetes. Diabetes 1999, 48, 1192-1197. [CrossRef] [PubMed]

126. Yeh, J.I.; Gulve, E.A.; Rameh, L.; Birnbaum, M.J. The effects of wortmannin on rat skeletal muscle. Dissociation of signaling pathways for insulin- and contraction-activated hexose transport. J. Biol. Chem. 1995, 270, 2107-2111. [CrossRef] [PubMed]

127. Lee, A.D.; Hansen, P.A.; Holloszy, J.O. Wortmannin inhibits insulin-stimulated but not contraction-stimulated glucose transport activity in skeletal muscle. FEBS Lett. 1995, 361, 51-54. [CrossRef]

128. Richter, E.A.; Kristiansen, S.; Wojtaszewski, J.; Daugaard, J.R.; Asp, S.; Hespel, P.; Kiens, B. Training effects on muscle glucose transport during exercise. Adv. Exp. Med. Biol. 1998, 441, 107-116. [PubMed]

129. Stuart, C.A.; Howell, M.E.A.; Baker, J.D.; Dykes, R.J.; Duffourc, M.M.; Ramsey, M.W.; Stone, M.H. Cycle training increased GLUT4 and activation of mammalian target of rapamycin in fast twitch muscle fibers. Med. Sci. Sports Exerc. 2010, 42, 96-106. [CrossRef]

130. Houmard, J.A.; Shinebarger, M.H.; Dolan, P.L.; Leggett-Frazier, N.; Bruner, R.K.; McCammon, M.R.; Israel, R.G.; Dohm, G.L. Exercise training increases GLUT-4 protein concentration in previously sedentary middle-aged men. Am. J. Physiol. 1993, 264, E896-E901. [CrossRef]

131. Dela, F.; Mikines, K.J.; von Linstow, M.; Secher, N.H.; Galbo, H. Effect of training on insulin-mediated glucose uptake in human muscle. Am. J. Physiol. 1992, 263, E1134-E1143. [CrossRef]

132. Greiwe, J.S.; Hickner, R.C.; Hansen, P.A.; Racette, S.B.; Chen, M.M.; Holloszy, J.O. Effects of endurance exercise training on muscle glycogen accumulation in humans. J. Appl. Physiol. 1999, 87, 222-226. [CrossRef] 
133. Little, J.P.; Safdar, A.; Wilkin, G.P.; Tarnopolsky, M.A.; Gibala, M.J. A practical model of low-volume high-intensity interval training induces mitochondrial biogenesis in human skeletal muscle: Potential mechanisms. J. Physiol. (Lond.) 2010, 588, 1011-1022. [CrossRef] [PubMed]

134. Short, K.R.; Vittone, J.L.; Bigelow, M.L.; Proctor, D.N.; Rizza, R.A.; Coenen-Schimke, J.M.; Nair, K.S. Impact of aerobic exercise training on age-related changes in insulin sensitivity and muscle oxidative capacity. Diabetes 2003, 52, 1888-1896. [CrossRef] [PubMed]

135. Burgomaster, K.A.; Cermak, N.M.; Phillips, S.M.; Benton, C.R.; Bonen, A.; Gibala, M.J. Divergent response of metabolite transport proteins in human skeletal muscle after sprint interval training and detraining. Am. J. Physiol. -Regul., Integr. Comp. Physiol. 2007, 292, R1970-R1976. [CrossRef] [PubMed]

136. Perry, C.G.R.; Heigenhauser, G.J.F.; Bonen, A.; Spriet, L.L. High-intensity aerobic interval training increases fat and carbohydrate metabolic capacities in human skeletal muscle. Appl. Physiol. Nutr. Metab. 2008, 33, 1112-1123. [CrossRef] [PubMed]

137. Banks, E.A.; Brozinick, J.T.; Yaspelkis, B.B.; Kang, H.Y.; Ivy, J.L. Muscle glucose transport, GLUT-4 content, and degree of exercise training in obese Zucker rats. Am. J. Physiol. 1992, 263, E1010-E1015. [CrossRef] [PubMed]

138. Neufer, P.D.; Shinebarger, M.H.; Dohm, G.L. Effect of training and detraining on skeletal muscle glucose transporter (GLUT4) content in rats. Can. J. Physiol. Pharm. 1992, 70, 1286-1290. [CrossRef] [PubMed]

139. Goodyear, L.J.; Hirshman, M.F.; Valyou, P.M.; Horton, E.S. Glucose Transporter Number, Function, and Subcellular Distribution in Rat Skeletal Muscle After Exercise Training. Diabetes 1992, 41, 1091-1099. [CrossRef] [PubMed]

140. Jørgensen, S.B.; Treebak, J.T.; Viollet, B.; Schjerling, P.; Vaulont, S.; Wojtaszewski, J.F.P.; Richter, E.A. Role of AMPK $\alpha 2$ in basal, training-, and AICAR-induced GLUT4, hexokinase II, and mitochondrial protein expression in mouse muscle. Am. J. Physiol. -Endocrinol. Metab. 2007, 292, E331-E339. [CrossRef]

141. Rodnick, K.J.; Henriksen, E.J.; James, D.E.; Holloszy, J.O. Exercise training, glucose transporters, and glucose transport in rat skeletal muscles. Am. J. Physiol. 1992, 262, C9-C14. [CrossRef]

142. Hansen, P.A.; Nolte, L.A.; Chen, M.M.; Holloszy, J.O. Increased GLUT-4 translocation mediates enhanced insulin sensitivity of muscle glucose transport after exercise. J. Appl. Physiol. 1998, 85, 1218-1222. [CrossRef]

143. Frøsig, C.; Rose, A.J.; Treebak, J.T.; Kiens, B.; Richter, E.A.; Wojtaszewski, J.F.P. Effects of endurance exercise training on insulin signaling in human skeletal muscle: Interactions at the level of phosphatidylinositol 3-kinase, Akt, and AS160. Diabetes 2007, 56, 2093-2102. [CrossRef] [PubMed]

144. Richter, E.A.; Garetto, L.P.; Goodman, M.N.; Ruderman, N.B. Muscle Glucose Metabolism following Exercise in the Rat: INCREASED SENSITIVITY TO INSULIN. J. Clin. Investig. 1982, 69, 785-793. [CrossRef] [PubMed]

145. Iwabe, M.; Kawamoto, E.; Koshinaka, K.; Kawanaka, K. Increased postexercise insulin sensitivity is accompanied by increased AS160 phosphorylation in slow-twitch soleus muscle. Physiol. Rep. 2014, 2, e12162. [CrossRef] [PubMed]

146. Cartee, G.D. Mechanisms for Greater Insulin-stimulated Glucose Uptake in Normal and Insulin Resistant Skeletal Muscle after Acute Exercise. Am. J. Physiol. Endocrinol. Metab. 2015, 309, E949-E959. [CrossRef] [PubMed]

147. Seki, Y.; Berggren, J.R.; Houmard, J.A.; Charron, M.J. Glucose transporter expression in skeletal muscle of endurance-trained individuals. Med. Sci. Sports Exerc. 2006, 38, 1088-1092. [CrossRef] [PubMed]

148. Lee, E.E.; Ma, J.; Sacharidou, A.; Mi, W.; Salato, V.K.; Nguyen, N.; Jiang, Y.; Pascual, J.M.; North, P.E.; Shaul, P.W.; et al. A Protein Kinase C Phosphorylation Motif in GLUT1 Affects Glucose Transport and is Mutated in GLUT1 Deficiency Syndrome. Mol. Cell 2015, 58, 845-853. [CrossRef] [PubMed]

149. Lisinski, I.; Schürmann, A.; Joost, H.G.; Cushman, S.W.; Al-Hasani, H. Targeting of GLUT6 (formerly GLUT9) and GLUT8 in rat adipose cells. Biochem. J. 2001, 358, 517-522. [CrossRef]

150. Flessner, L.B.; Moley, K.H. Similar [DE]XXXL[LI] motifs differentially target GLUT8 and GLUT12 in Chinese hamster ovary cells. Traffic 2009, 10, 324-333. [CrossRef]

151. Holten, M.K.; Zacho, M.; Gaster, M.; Juel, C.; Wojtaszewski, J.F.P.; Dela, F. Strength training increases insulin-mediated glucose uptake, GLUT4 content, and insulin signaling in skeletal muscle in patients with type 2 diabetes. Diabetes 2004, 53, 294-305. [CrossRef]

152. Yaspelkis, B.B.; Singh, M.K.; Trevino, B.; Krisan, A.D.; Collins, D.E. Resistance training increases glucose uptake and transport in rat skeletal muscle. Acta Physiol. Scand. 2002, 175, 315-323. [CrossRef] 
153. Young, J.C.; Kandarian, S.C.; Kurowski, T.G. Skeletal muscle glucose uptake following overload-induced hypertrophy. Life Sci. 1992, 50, 1319-1325. [CrossRef]

154. Pereira, R.O.; Wende, A.R.; Olsen, C.; Soto, J.; Rawlings, T.; Zhu, Y.; Riehle, C.; Abel, E.D. GLUT1 deficiency in cardiomyocytes does not accelerate the transition from compensated hypertrophy to heart failure. J. Mol. Cell. Cardiol. 2014, 72, 95-103. [CrossRef] [PubMed]

155. Lee, Y.-C.; Huang, H.-Y.; Chang, C.-J.; Cheng, C.-H.; Chen, Y.-T. Mitochondrial GLUT10 facilitates dehydroascorbic acid import and protects cells against oxidative stress: Mechanistic insight into arterial tortuosity syndrome. Hum. Mol. Genet. 2010, 19, 3721-3733. [CrossRef] [PubMed]

156. Syu, Y.-W.; Lai, H.-W.; Jiang, C.-L.; Tsai, H.-Y.; Lin, C.-C.; Lee, Y.-C. GLUT10 maintains the integrity of major arteries through regulation of redox homeostasis and mitochondrial function. Hum. Mol. Genet. 2018, 27, 307-321. [CrossRef] [PubMed]

157. Halseth, A.E.; Bracy, D.P.; Wasserman, D.H. Overexpression of hexokinase II increases insulinand exercise-stimulated muscle glucose uptake in vivo. Am. J. Physiol. -Endocrinol. Metab. 1999, 276, E70-E77. [CrossRef] [PubMed]

158. O’Doherty, R.M.; Bracy, D.P.; Osawa, H.; Wasserman, D.H.; Granner, D.K. Rat skeletal muscle hexokinase II mRNA and activity are increased by a single bout of acute exercise. Am. J. Physiol. 1994, 266, E171-E178. [CrossRef]

159. Koval, J.A.; DeFronzo, R.A.; O’Doherty, R.M.; Printz, R.; Ardehali, H.; Granner, D.K.; Mandarino, L.J. Regulation of hexokinase II activity and expression in human muscle by moderate exercise. Am. J. Physiol. -Endocrinol. Metab. 1998, 274, E304-E308. [CrossRef]

160. Bonadonna, R.C.; Del Prato, S.; Bonora, E.; Saccomani, M.P.; Gulli, G.; Natali, A.; Frascerra, S.; Pecori, N.; Ferrannini, E.; Bier, D.; et al. Roles of glucose transport and glucose phosphorylation in muscle insulin resistance of NIDDM. Diabetes 1996, 45, 915-925. [CrossRef]

161. Fueger, P.T.; Heikkinen, S.; Bracy, D.P.; Malabanan, C.M.; Pencek, R.R.; Laakso, M.; Wasserman, D.H. Hexokinase II partial knockout impairs exercise-stimulated glucose uptake in oxidative muscles of mice. Am. J. Physiol. -Endocrinol. Metab. 2003, 285, E958-E963. [CrossRef]

162. Fueger, P.T.; Lee-Young, R.S.; Shearer, J.; Bracy, D.P.; Heikkinen, S.; Laakso, M.; Rottman, J.N.; Wasserman, D.H. Phosphorylation Barriers to Skeletal and Cardiac Muscle Glucose Uptakes in High-Fat-Fed Mice. Diabetes 2007, 56, 2476-2484. [CrossRef]

163. Barnard, R.J.; Peter, J.B. Effect of training and exhaustion on hexokinase activity of skeletal muscle. J. Appl. Physiol. 1969, 27, 691-695. [CrossRef] [PubMed]

164. Lamb, D.; Peter, J.; Jeffress, R.; Wallace, H. Glycogen, hexokinase, and glycogen synthetase adaptations to exercise. Am. J. Physiol. -Leg. Content 1969, 217, 1628-1632. [CrossRef] [PubMed]

165. Bylund, A.C.; Bjurö, T.; Cederblad, G.; Holm, J.; Lundholm, K.; Sjöström, M.; Ängquist, K.A.; Scherstén, T. Physical training in man-Keletal muscle metabolism in relation to muscle morphology and running ability. Eur. J. Appl. Physiol. Occup. Physiol. 1977, 36, 151-169. [CrossRef] [PubMed]

166. Mandroukas, K.; Krotkiewski, M.; Hedberg, M.; Wroblewski, Z.; Björntorp, P.; Grimby, G. Physical training in obese women-Effects of muscle morphology, biochemistry and function. Eur. J. Appl. Physiol. Occup. Physiol. 1984, 52, 355-361. [CrossRef] [PubMed]

167. Röckl, K.S.C.; Hirshman, M.F.; Brandauer, J.; Fujii, N.; Witters, L.A.; Goodyear, L.J. Skeletal muscle adaptation to exercise training: AMP-activated protein kinase mediates muscle fiber type shift. Diabetes 2007, 56, 2062-2069. [CrossRef] [PubMed]

168. Liu, X.; Wang, Y.; Gao, R.; Xing, Y.; Li, X.; Wang, Z. Serum metabolomic response to exercise training in spontaneously hypertensive rats. J. Am. Soc. Hypertens.: JASH 2017, 11, 428-436. [CrossRef]

169. Real-Hohn, A.; Navegantes, C.; Ramos, K.; Ramos-Filho, D.; Cahuê, F.; Galina, A.; Salerno, V.P. The synergism of high-intensity intermittent exercise and every-other-day intermittent fasting regimen on energy metabolism adaptations includes hexokinase activity and mitochondrial efficiency. PLoS ONE 2018, 13, e0202784. [CrossRef]

170. Brandt, N.; Dethlefsen, M.M.; Bangsbo, J.; Pilegaard, H. PGC-1 $\alpha$ and exercise intensity dependent adaptations in mouse skeletal muscle. PLoS ONE 2017, 12, e0185993. [CrossRef]

171. Steenberg, D.E.; Jørgensen, N.B.; Birk, J.B.; Sjøberg, K.A.; Kiens, B.; Richter, E.A.; Wojtaszewski, J.F.P. Exercise training reduces the insulin-sensitizing effect of a single bout of exercise in human skeletal muscle. J. Physiol. 2019, 597, 89-103. [CrossRef] 
172. Kleinert, M.; Parker, B.L.; Jensen, T.E.; Raun, S.H.; Pham, P.; Han, X.; James, D.E.; Richter, E.A.; Sylow, L. Quantitative proteomic characterization of cellular pathways associated with altered insulin sensitivity in skeletal muscle following high-fat diet feeding and exercise training. Sci. Rep. 2018, 8, 10723. [CrossRef]

173. Thibault, M.C.; Simoneau, J.A.; Côté, C.; Boulay, M.R.; Lagassé, P.; Marcotte, M.; Bouchard, C. Inheritance of human muscle enzyme adaptation to isokinetic strength training. Hum. Hered. 1986, 36, 341-347. [CrossRef] [PubMed]

174. Green, H.J.; Dahly, A.; Shoemaker, K.; Goreham, C.; Bombardier, E.; Ball-Burnett, M. Serial effects of high-resistance and prolonged endurance training on $\mathrm{Na}+\mathrm{K}+$ pump concentration and enzymatic activities in human vastus lateralis. Acta Physiol. Scand. 1999, 165, 177-184. [CrossRef] [PubMed]

175. Tesch, P.A.; Komi, P.V.; Häkkinen, K. Enzymatic adaptations consequent to long-term strength training. Int. J. Sports Med. 1987, 8 Suppl 1, 66-69. [CrossRef]

176. Manchester, J.; Skurat, A.V.; Roach, P.; Hauschka, S.D.; Lawrence, J.C. Increased glycogen accumulation in transgenic mice over expressing glycogen synthase in skeletal muscle. Proc. Natl. Acad. Sci. USA 1996, 93, 10707-10711. [CrossRef] [PubMed]

177. Xirouchaki, C.E.; Mangiafico, S.P.; Bate, K.; Ruan, Z.; Huang, A.M.; Tedjosiswoyo, B.W.; Lamont, B.; Pong, W.; Favaloro, J.; Blair, A.R.; et al. Impaired glucose metabolism and exercise capacity with muscle-specific glycogen synthase 1 (gys1) deletion in adult mice. Mol. Metab. 2016, 5, 221-232. [CrossRef] [PubMed]

178. Perseghin, G.; Price, T.; Petersen, K.; Roden, M.; Cline, G.; Gerow, K.; Rothman, D.; Shulman, G. Increased Glucose Transport-Phosphorylation and Muscle Glycogen Synthesis After Exercise Training in Insulin-Resistant. New Engl. J. Med. 1996, 335, 1357-1362. [CrossRef] [PubMed]

179. Manabe, Y.; Gollisch, K.S.C.; Holton, L.; Kim, Y.-B.; Brandauer, J.; Fujii, N.L.; Hirshman, M.F.; Goodyear, L.J. Exercise training-induced adaptations associated with increases in skeletal muscle glycogen content. FEBS J. 2013, 280, 916-926. [CrossRef]

180. Gollnick, P.D.; Armstrong, R.B.; Saltin, B.; Saubert, C.W.; Sembrowich, W.L.; Shepherd, R.E. Effect of training on enzyme activity and fiber composition of human skeletal muscle. J. Appl. Physiol. 1973, 34, 107-111. [CrossRef]

181. Hickner, R.C.; Fisher, J.S.; Hansen, P.A.; Racette, S.B.; Mier, C.M.; Turner, M.J.; Holloszy, J.O. Muscle glycogen accumulation after endurance exercise in trained and untrained individuals. J. Appl. Physiol. 1997, 83, 897-903. [CrossRef]

182. Bergström, J.; Hermansen, L.; Hultman, E.; Saltin, B. Diet, Muscle Glycogen and Physical Performance. Acta Physiol. Scand. 1967, 71, 140-150. [CrossRef]

183. Murray, B.; Rosenbloom, C. Fundamentals of glycogen metabolism for coaches and athletes. Nutr. Rev. 2018, 76, 243-259. [CrossRef]

184. Haun, C.T.; Vann, C.G.; Mobley, C.B.; Osburn, S.C.; Mumford, P.W.; Roberson, P.A.; Romero, M.A.; Fox, C.D.; Parry, H.A.; Kavazis, A.N.; et al. Pre-training Skeletal Muscle Fiber Size and Predominant Fiber Type Best Predict Hypertrophic Responses to 6 Weeks of Resistance Training in Previously Trained Young Men. Front. in Physiol. 2019, 10, 297. [CrossRef]

185. Haun, C.T.; Vann, C.G.; Osburn, S.C.; Mumford, P.W.; Roberson, P.A.; Romero, M.A.; Fox, C.D.; Johnson, C.A.; Parry, H.A.; Kavazis, A.N.; et al. Muscle fiber hypertrophy in response to 6 weeks of high-volume resistance training in trained young men is largely attributed to sarcoplasmic hypertrophy. PLOS ONE 2019, 14, e0215267. [CrossRef]

186. MacDougall, J.D.; Ward, G.R.; Sale, D.G.; Sutton, J.R. Biochemical adaptation of human skeletal muscle to heavy resistance training and immobilization. J. Appl. Physiol. 1977, 43, 700-703. [CrossRef]

187. Tarui, S.; Giichi, O.; Ikura, Y.; Tanaka, T.; Suda, M.; Nishikawa, M. Phosphofructokinase deficiency in skeletal muscle. A new type of glycogenosis. Biochem. Biophys. Res. Commun. 1965, 19, 517-523. [CrossRef]

188. García, M.; Pujol, A.; Ruzo, A.; Riu, E.; Ruberte, J.; Arbós, A.; Serafín, A.; Albella, B.; Felíu, J.E.; Bosch, F. Phosphofructo-1-kinase deficiency leads to a severe cardiac and hematological disorder in addition to skeletal muscle glycogenosis. PLoS Genet. 2009, 5, e1000615. [CrossRef] [PubMed]

189. Svensson, K.; Dent, J.R.; Tahvilian, S.; Martins, V.F.; Sathe, A.; Ochala, J.; Patel, M.S.; Schenk, S. Defining the contribution of skeletal muscle pyruvate dehydrogenase $\alpha 1$ to exercise performance and insulin action. Am. J. Physiol. -Endocrinol. Metab. 2018, 315, E1034-E1045. [CrossRef] [PubMed]

190. Metzger, J.M.; Fitts, R.H. Contractile and biochemical properties of diaphragm: Effects of exercise training and fatigue. J. Appl. Physiol. 1986, 60, 1752-1758. [CrossRef] [PubMed] 
191. Davidson, S.R.; Burnett, M.; Hoffman-Goetz, L. Training effects in mice after long-term voluntary exercise. Med. Sci. Sports Exerc. 2006, 38, 250-255. [CrossRef] [PubMed]

192. LeBlanc, P.J.; Peters, S.J.; Tunstall, R.J.; Cameron-Smith, D.; Heigenhauser, G.J.F. Effects of aerobic training on pyruvate dehydrogenase and pyruvate dehydrogenase kinase in human skeletal muscle. J. Physiol. 2004, 557, 559-570. [CrossRef] [PubMed]

193. Ngo, K.T.A.; Denis, C.; Saafi, M.A.; Feasson, L.; Verney, J. Endurance but not resistance training increases intra-myocellular lipid content and $\beta$-hydroxyacyl coenzyme A dehydroge in active elderly men. Acta Physiol 2012, 205, 133-144. [CrossRef]

194. Love, D.C.; Hanover, J.A. The Hexosamine Signaling Pathway: Deciphering the "O-GlcNAc Code". Sci. Signal. 2005, 2005, re13. [CrossRef]

195. Shi, H.; Munk, A.; Nielsen, T.S.; Daughtry, M.R.; Larsson, L.; Li, S.; Høyer, K.F.; Geisler, H.W.; Sulek, K.; Kjøbsted, R.; et al. Skeletal muscle O-GlcNAc transferase is important for muscle energy homeostasis and whole-body insulin sensitivity. Mol. Metab. 2018, 11, 160-177. [CrossRef] [PubMed]

196. Hebert, L.F.; Daniels, M.C.; Zhou, J.; Crook, E.D.; Turner, R.L.; Simmons, S.T.; Neidigh, J.L.; Zhu, J.S.; Baron, A.D.; McClain, D.A. Overexpression of glutamine:fructose-6-phosphate amidotransferase in transgenic mice leads to insulin resistance. J. Clin. Investig. 1996, 98, 930-936. [CrossRef] [PubMed]

197. Toivonen, M.H.M.; Pöllänen, E.; Ahtiainen, M.; Suominen, H.; Taaffe, D.R.; Cheng, S.; Takala, T.; Kujala, U.M.; Tammi, M.I.; Sipilä, S.; et al. OGT and OGA expression in postmenopausal skeletal muscle associates with hormone replacement therapy and muscle cross-sectional area. Exp. Gerontol. 2013, 48, 1501-1504. [CrossRef] [PubMed]

198. Hortemo, K.H.; Lunde, P.K.; Anonsen, J.H.; Kvaloy, H.; Munkvik, M.; Rehn, T.A.; Sjaastad, I.; Lunde, I.G.; Aronsen, J.M.; Sejersted, O.M. Exercise training increases protein O-GlcNAcylation in rat skeletal muscle. Physiol. Rep. 2016, 4, 1-20. [CrossRef]

199. Meijer, A.E. The Pentose Phosphate Pathway in Skeletal Muscle Under Patho-Physiological Conditions. Prog. Histochem. Cytochem. 1991, 22, 1-118.

200. Wagner, K.R.; Kauffman, F.C.; Max, S.R. The pentose phosphate pathway in regenerating skeletal muscle. Biochem. J. 1978, 170, 17-22. [CrossRef]

201. Wu, C.-L.; Satomi, Y.; Walsh, K. RNA-seq and metabolomic analyses of Akt1-mediated muscle growth reveals regulation of regenerative pathways and changes in the muscle secretome. BMC Genomics 2017, 18, 181. [CrossRef]

202. Battistuzzi, G.; D’Urso, M.; Toniolo, D.; Persico, G.M.; Luzzatto, L. Tissue-specific levels of human glucose-6-phosphate dehydrogenase correlate with methylation of specific sites at the $3^{\prime}$ end of the gene. Proc. Natl. Acad. Sci. USA 1985, 82, 1465-1469. [CrossRef]

203. Glock, G.E.; Mclean, P. Levels of Enzymes of the Direct Oxidative Pathway of Carbohydrate Metabolism in Mammalian Tissues and Tumours. Biochem. J. 1954, 56, 171-175. [CrossRef] [PubMed]

204. Schwane, J.A.; Armstrong, R.B. Effect of training on skeletal muscle injury from downhill running in rats. J. Appl. Physiol. 1983, 55, 969-975. [CrossRef] [PubMed]

205. Tsuda, S.; Hayashi, T.; Egawa, T. The Effects of Caffeine on Metabolomic Responses to Muscle Contraction in Rat Skeletal Muscle. Nutrients 2019, 11, 1819. [CrossRef] [PubMed]

206. Lira, V.A.; Benton, C.R.; Yan, Z.; Bonen, A. PGC-1 $\alpha$ regulation by exercise training and its influences on muscle function and insulin sensitivity. Am. J. Physiol. -Endocrinol. Metab. 2010, 299, E145-E161. [CrossRef] [PubMed]

207. Hatazawa, Y.; Senoo, N.; Tadaishi, M.; Ogawa, Y.; Ezaki, O.; Kamei, Y.; Miura, S. Metabolomic Analysis of the Skeletal Muscle of Mice Overexpressing PGC-1 $\alpha$. PLoS ONE 2015, 10, e0129084. [CrossRef]

208. Schiaffino, S.; Mammucari, C. Regulation of skeletal muscle growth by the IGF1-Akt/PKB pathway: Insights from genetic models. Skelet. Muscle 2011, 1, 4. [CrossRef] [PubMed]

209. Manning, B.D.; Toker, A. AKT/PKB Signaling: Navigating the Network. Cell 2017, 169, 381-405. [CrossRef]

(C) 2019 by the authors. Licensee MDPI, Basel, Switzerland. This article is an open access article distributed under the terms and conditions of the Creative Commons Attribution (CC BY) license (http://creativecommons.org/licenses/by/4.0/). 